University of Nebraska - Lincoln

DigitalCommons@University of Nebraska - Lincoln

Nutrition and Health Sciences -- Faculty

Publications

Nutrition and Health Sciences, Department of

2021

\title{
Essential role of systemic iron mobilization and redistribution for adaptive thermogenesis through HIF2- $\alpha$ /hepcidin axis
}

Jin-Seon Yook

Mikyoung You

Jiyoung Kim

University of Nebraska-Lincoln

Rong Fan

See next page for additional authors

Follow this and additional works at: https://digitalcommons.unl.edu/nutritionfacpub

Part of the Human and Clinical Nutrition Commons, Molecular, Genetic, and Biochemical Nutrition Commons, and the Other Nutrition Commons

This Article is brought to you for free and open access by the Nutrition and Health Sciences, Department of at DigitalCommons@University of Nebraska - Lincoln. It has been accepted for inclusion in Nutrition and Health Sciences -- Faculty Publications by an authorized administrator of DigitalCommons@University of Nebraska Lincoln. 


\section{Authors}

Jin-Seon Yook, Mikyoung You, Jiyoung Kim, University of Nebraska-Lincoln, Rong Fan, Bhanwar Lal Puniya, Tomáš Helikar, Sophie Vaulont, Jean-Christophe Deschemin, Meshail Oklar, Liwei Xie, Manik C. Ghosh, Tracey A. Rouault, Jaekwon Lee, and Soonkyu Chung 


\title{
Essential role of systemic iron mobilization and redistribution for adaptive thermogenesis through HIF2- $\alpha$ /hepcidin axis
}

\author{
Jin-Seon Yook ${ }^{\mathrm{a}, 1}$, Mikyoung You ${ }^{\mathrm{a}, 1}$, Jiyoung Kim ${ }^{\mathrm{b}, 1}$, Ashley M. Toneyc, Rong Fanc, Bhanwar Lal Puniyad ${ }^{\mathrm{c}}$,

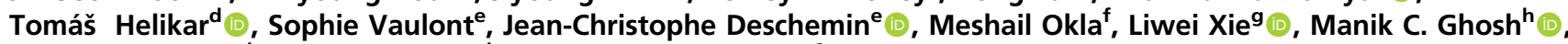

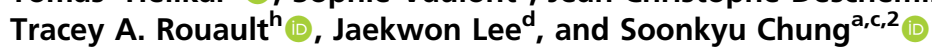

\begin{abstract}
aDepartment of Nutrition, University of Massachusetts Amherst, Amherst, MA 01003; bepartment of Food and Nutrition, Kyungnam College of Information \& Technology, Pusan 47011, Republic of Korea; 'Department of Nutrition and Health Science, University of Nebraska-Lincoln, Lincoln, NE

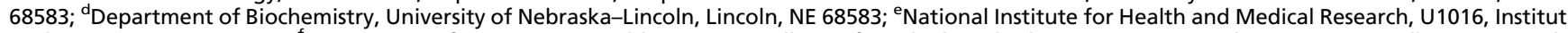
Cochin, 75014 Paris, France; 'Department of Community Health Sciences, College of Applied Medical Sciences, King Saud University, Riyadh 12372, Saudi Arabia; ' ${ }^{9}$ State Key Laboratory of Applied Microbiology Southern China, Institute of Microbiology, Guangdong Academy of Sciences, Guangzhou 510070, China; and hection on Human Iron Metabolism, National Institute of Child Health and Human Development, NIH, Bethesda, MD 20892
\end{abstract}

Edited by C. Ronald Kahn, Harvard Medical School, Boston, MA, and approved August 30, 2021 (received for review May 18, 2021)

Iron is an essential biometal, but is toxic if it exists in excess. Therefore, iron content is tightly regulated at cellular and systemic levels to meet metabolic demands but to avoid toxicity. We have recently reported that adaptive thermogenesis, a critical metabolic pathway to maintain whole-body energy homeostasis, is an irondemanding process for rapid biogenesis of mitochondria. However, little information is available on iron mobilization from storage sites to thermogenic fat. This study aimed to determine the iron-regulatory network that underlies beige adipogenesis. We hypothesized that thermogenic stimulus initiates the signaling interplay between adipocyte iron demands and systemic iron liberation, resulting in iron redistribution into beige fat. To test this hypothesis, we induced reversible activation of beige adipogenesis in C57BL/ 6 mice by administering a $\beta 3$-adrenoreceptor agonist $\mathrm{CL}$ 316,243 (CL). Our results revealed that $\mathrm{CL}$ stimulation induced the iron-regulatory protein-mediated iron import into adipocytes, suppressed hepcidin transcription, and mobilized iron from the spleen. Mechanistically, CL stimulation induced an acute activation of hypoxia-inducible factor 2- $\alpha$ (HIF2- $\alpha$ ), erythropoietin production, and splenic erythroid maturation, leading to hepcidin suppression. Disruption of systemic iron homeostasis by pharmacological HIF2- $\alpha$ inhibitor PT2385 or exogenous administration of hepcidin-25 significantly impaired beige fat development. Our findings suggest that securing iron availability via coordinated interplay between renal hypoxia and hepcidin down-regulation is a fundamental mechanism to activate adaptive thermogenesis. It also provides an insight into the effects of adaptive thermogenesis on systemic iron mobilization and redistribution.

adaptive thermogenesis | HIF2- $\alpha$ | hepcidin | iron | hypoxia

T hermogenic adipocytes convert chemical energy from carbohydrates and fats to heat to defend body temperature in response to cold environments or divert excess fat away from storage. The regulated heat production in response to environmental stimuli is defined as adaptive thermogenesis, significantly contributing to whole-body energy expenditure (1). Humans possess metabolically active thermogenic fats in the deeper neck and supraclavicular areas (2-4). An increase of thermogenic fat mass or activity has been demonstrated to relieve the metabolic burden and improve energy metabolism, opening up a new therapeutic avenue to exploit the adaptive thermogenic process to treat obesity and type 2 diabetes (5).

The thermogenic capacity of adipocytes is dependent on mitochondrial biogenesis, which is an iron-demanding pathway (6). The advent of the brownish tint of thermogenic fats reflects the abundance of mitochondrial heme-containing proteins $(7,8)$ and iron-sulfur ( $\mathrm{Fe}-\mathrm{S})$ clusters, and both heme and nonheme iron are critical for mitochondrial function (e.g., tricarboxylic acid cycle, respiration, and fatty acid oxidation) $(9,10)$. The initiation of beige adipogenesis by $\beta 3$-adrenoreceptor (ADRB3), so-called browning, rapidly increases mitochondrial biogenesis (11), while the loss of thermogenic function, so-called whitening, reduces mitochondrial content through autophagic degradation (12). Moreover, iron per se has been shown to serve as a signaling molecule to regulate the transcription of mitochondrial proteins $(13,14)$. These studies suggest that the regulation of iron homeostasis is a crucial determinant for the development of thermogenic fat. Currently, iron regulation in nonhematopoietic cells has yet to be understood, and the importance of iron regulation in governing the metabolic function of adipocytes has been understudied. We recently started understanding the differential role of iron homeostasis in white versus brown adipose tissue (6). The iron regulatory network

\section{Significance}

Adaptive thermogenesis is a metabolic switch that converts the metabolic status of fat tissue from energy conservation to energy release into heat, thereby significantly attenuating the energy burden of obesity and diabetes. It is well known that increased iron content and subsequent mitochondrial formation are required for thermogenic activation. However, no information is available on how iron is mobilized from storage sites into thermogenic fat. Here, we show that acute hypoxia and stress-erythropoiesis responses facilitate securing iron required for white-to-beige fat conversion. Our study revealed that hepcidin down-regulation is a fundamental mechanism required for beige fat development. It also suggests that systemic iron modulation could be a promising strategy to curb obesity and metabolic complications by augmenting adaptive thermogenesis.

Author contributions: J.-S.Y., M.O., and S.C. designed research; J.-S.Y., M.Y., J.K., R.F. B.L.P., J.-C.D., M.O., M.C.G., and J.L. performed research; B.L.P., S.V., L.X., M.C.G., and T.A.R. contributed new reagents/analytic tools; J.-S.Y., M.Y., J.K., A.M.T., R.F., B.L.P., T.H., S.V., J.-C.D., M.O., M.C.G., T.A.R., J.L., and S.C. analyzed data; J.-S.Y., J.K., and S.C. wrote the paper; L.X. provided critical discussion on HIF1 deletion in adipocytes; T.A.R. provided a critical discussion on IRP regulation; J.L. provided a critical review of the manuscript; and S.C. supervised the project, interpreted data, and edited the manuscript.

The authors declare no competing interest.

This article is a PNAS Direct Submission.

Published under the PNAS license.

1J.-S.Y., M.Y., and J.K. contributed equally to this work.

${ }^{2}$ To whom correspondence may be addressed. Email: soonkyuchung@umass.edu.

This article contains supporting information online at https://www.pnas.org/lookup/suppl/ doi:10.1073/pnas.2109186118/-/DCSupplemental.

Published September 30, 2021. 
underlying metabolic conversion from energy-conserving white fat to energy-release beige fat is of interest and remains largely unknown.

Iron homeostasis is a highly regulated process orchestrated by iron-regulatory proteins (IRPs) $(15,16)$, the intracellular iron sensor, and hepcidin, the master iron-regulatory hormone (17). IRPs control the fate of messenger RNAs (mRNAs) that encode proteins involved in iron homeostasis or adaptive responses to iron deficiency. In low-iron status, IRP1 loses aconitase activity and binds to the target mRNAs possessing iron response elements (IRE), including 1) transferrin receptor 1 (TFR1) and divalent metal transporter 1 (DMT1) for iron import and distribution, 2) ferritin light $(F T L)$ and heavy chain $(F T H)$ for iron storage, and 3 ) ferroportin $(F P N)$ for iron export. Similarly, IRP2, which undergoes proteasomal degradation by iron-stabilized E3 ligase component (FBXL5) at iron-replete conditions, binds to the IRE of the target mRNAs at iron-deplete conditions. The IRP/IRE binding at the $5^{\prime}$ untranslated region (UTR) region of the ferritin and FPN mRNA inhibits translation, leading to increased availability of free iron. In contrast, IRP/IRE binding to at the $3^{\prime}$ UTR region of TFR 1 and DMT1 transcripts increases their stability and translation, enhancing iron uptake $(18,19)$.

Intracellular iron homeostasis is tightly linked with systemic iron levels by the iron regulatory hormone hepcidin. Hepcidin is a peptide hormone that is primarily released from the liver (20). It reduces extracellular iron in the body by promoting the degradation of the iron exporter FPN (21). Therefore, the suppression of hepcidin production increases intestinal iron entry into the portal circulation and promotes iron liberation from storage cells (22). The serum hepcidin concentration is primarily controlled at the level of transcription in hepatocytes. Bone morphogenetic protein 6 (BMP6)/SMAD signaling pathway is critical for hepcidin control in response to iron demands (23-25).

It is also well known that oxygen homeostasis regulates iron metabolism in hematopoietic cells, although this relationship has not been fully understood in nonhematopoietic cells. Iron and oxygen homeostasis are intertwined both at the cellular and systemic levels. Consistently, beige adipogenesis is associated with rapid elevation of systemic oxygen uptake (26) and adipose tissue hypoxia $(27,28)$. Also, administering erythropoietin (EPO), a kidney-derived hormone that plays a crucial role in red blood cell production in response to falling oxygen levels, promotes beige adipogenesis (29). However, despite accumulating hints, few studies examined the signaling interplay between iron and oxygen metabolism during beige adipogenesis. The current study aimed to investigate the underlying mechanism by which altered iron/oxygen homeostasis controls the metabolic conversion of beige fat. Here, we demonstrated that ADRB3 activation increased intracellular IRP/IRE activity and multiorgan-involved iron liberation, leading to iron redistribution.

\section{Results}

Activation of the IRP/IRE Signaling Pathway in Adipocytes upon Thermogenic Stimulation. For induction of browning, C57BL/6 mice were administered with either saline (Control) or ADRB3 agonist CL 316,243 (CL) for five consecutive days. For the reversal of browning (whitening), the mice that received $C L$ for the first $5 \mathrm{~d}$ were injected with saline for an additional $5 \mathrm{~d}$ for CL withdrawal (CL/WD). The reversible heat release in response to $\mathrm{CL}$ and $\mathrm{CL} / \mathrm{WD}$ was captured by an infrared (IR) camera (Fig. $1 A$ ). The CL stimulation increased the conspicuous brownish tint and beige adipocyte-specific multilocular morphology in the inguinal white adipose tissue (iWAT) (Fig. $1 B$ ). Consistent with our previous findings (6), thermogenic activation by CL treatment increased the total iron content in the iWAT, both heme and nonheme iron. In addition, cellular fractionation revealed that both cytosolic and mitochondrial iron content was increased in response to CL treatment (Fig. $1 C$ ).
Next, we examined the molecular factors involved in iron handling in browning and whitening. Upon CL, there was a dramatic increase in TFR1 at both protein and gene levels correlating with uncoupling protein 1 (UCP1) expression, a universal marker for thermogenic fat (Fig. $1 D$ and $E$ ). The immunostaining of TFR1 further revealed that the multilocular adipocytes expressed higher levels of TFR1 than unilocular adipocytes upon CL stimulation $($ Fig. $1 F)$. In response to $\mathrm{CL}$, cytochrome $c(\mathrm{CytC})$ and oxidative phosphorylation (OxPhos) proteins were increased (Fig. $1 D)$. These changes were under the control of IRPs, evidenced by a robust accumulation of IRP2 and decreased FBXL5 upon CL stimulation. Accordingly, CL-stimulation increased the protein levels of DMT1 and decreased the FTL (Fig. 1D), implicating an increase of IRP/IRE signaling pathway. During whitening, these iron-handling protein expressions were reversed, concurrent with decreased UCP1 expression (Fig. 1D). The activation of the IRP/ IRE signaling pathway was recapitulated upon cold temperature. The induction of UCP1 by chronic cold temperature $\left(8^{\circ} \mathrm{C}\right)$ was simultaneous with IRP2 stabilization, but not IRP1, and increased TFR1 and DMT1 levels in the iWAT (Fig. 1G). This inverse relationship between FBXL5 and IRP2 was also evident during cold stimulation, displaying a near absence of FBXL5 and IRP2 accumulation (Fig. $1 G$ ). We performed an electrophoretic mobility shift assay (EMSA) using an IRDye700-labeled IRE probe to confirm the physical interactions between IRP and IRE. The IRP/ IRE binding was barely noticeable in the iWAT at the basal levels. However, IRP/IRE binding was increased in response to CL treatment (Fig. 1H). The coincubation with an increasing dose of nonlabeled competitor IRE diminished the IRDye700-labeled IRP/IRE band, validating the specificity of IRP/IRE binding (Fig. $1 H)$. To further understand the impact of IRP activation in adipocyte iron homeostasis, we also analyzed the profile changes of iron metabolism-related genes by leveraging the published transcriptome datasets (ArrayExpress: E-MTAB-3978) (12). Consistent with our previous findings, the mitochondrial OxPhos genes and Tfr 1 were dramatically increased in beige fat ( $5 \mathrm{~d}$ of CL treatment) and then slowly declined in whitening periods $(5,10$, and $30 \mathrm{~d}$ after CL withdrawal) (Fig. 1I). In contrast, many of the selected genes, including ferroxidase enzymes involved in the function of FPN (i.e., hephaestin [Heph] and ceruloplasmin $[C p]$ ) (30) and ironstorage (i.e., ferritin light $F t l$ and heavy chain $F t h l$ ) were reduced during beige adipocyte development. However, their levels slowly recovered during whitening (Fig. $1 I$ and SI Appendix, Table 1).

The role of IRP in adipose tissue browning was assessed by using IRP knockout mice. The Irp2 knockout mice (Irp $\left.2^{-/-}\right)$ failed to up-regulate UCP1 and IRP/IRE signaling responses (i.e., increased TFR1 and decreased FTL) and beige-specific morphology in the iWAT upon cold exposure at $8^{\circ} \mathrm{C}$ (SI Appendix, Fig. $1 A$ ). The genetic ablation of Irp1 induced a compensatory increase of IRP2 expression in the iWAT at room temperature $(22$ $\left.{ }^{\circ} \mathrm{C}\right)$. However, the lack of Irp1 failed to accumulate IRP2 upon thermogenic stimuli at $8{ }^{\circ} \mathrm{C}$. Furthermore, the cold-mediated UCP1 expression and beige-specific morphology were abolished in Irp1 ${ }^{-/-}$mice (SI Appendix, Fig. 1B). These results indicate that 1) deregulation of IRP/IRE signaling interferes with beige fat development and 2) IRP1 and IRP2 seem to play distinctive roles in beige fat development.

Systemic Iron Mobilization via Hepcidin Suppression upon Thermogenic Stimulation. We next explored whether ADR3 activation by CL also alters hepcidin levels, the central regulator for systemic iron homeostasis, by degrading the iron exporter ferroportin (FPN) (22). In the same animal models of Fig. $1 A$, CL stimulation induced a significant decrease in serum levels of hepcidin and hepatic Hampl gene expression, which were reversed in CL/WD (Fig. 2A). The transcriptional repression of Hamp1 was due to the suppression of SMAD signaling given the reduced SMAD1/5/8 phosphorylation (Fig. $2 B$ ). The other target genes containing 


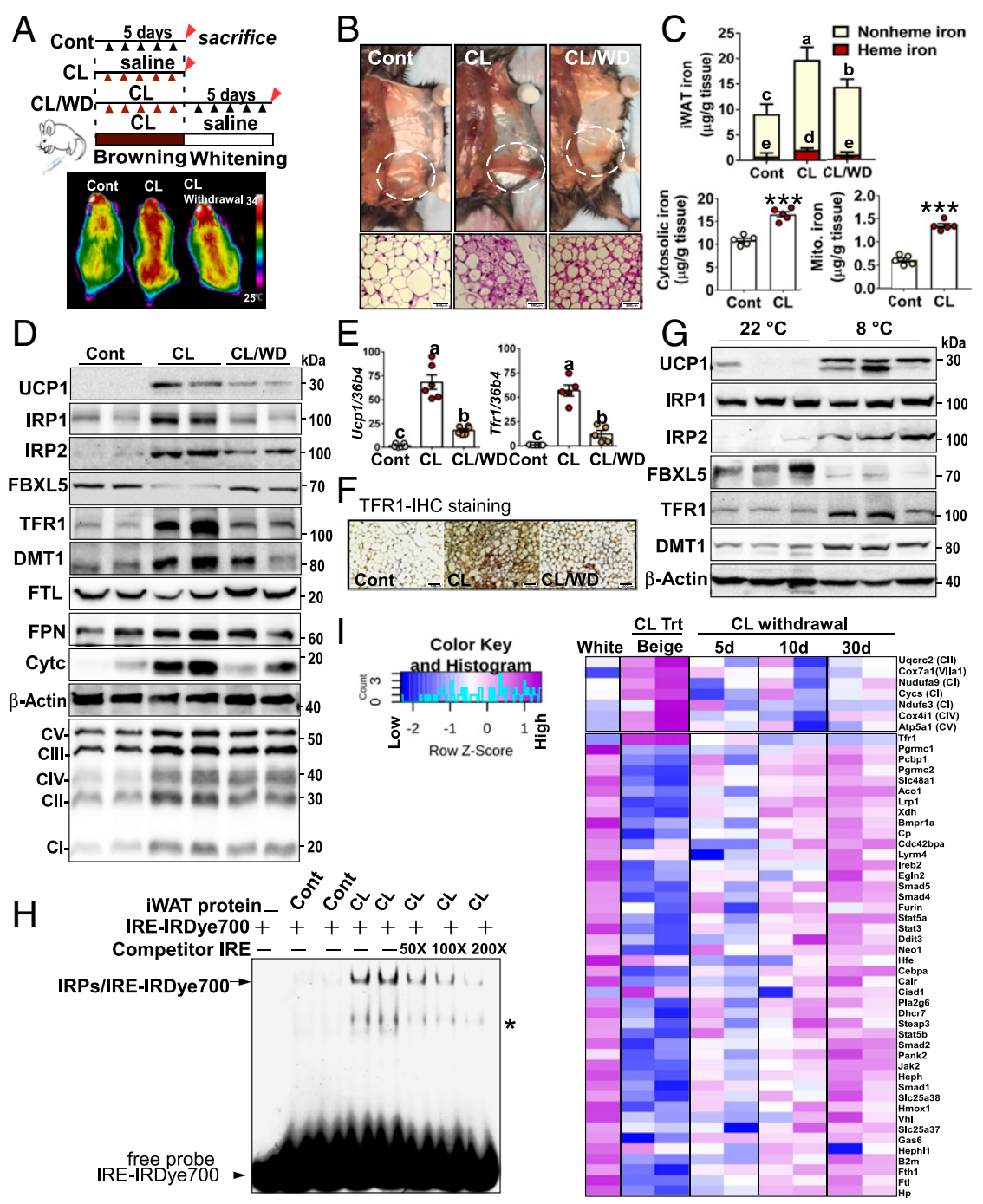

Fig. 1. IRP/IRE signaling responses and iron import in browning adipose tissue. (A) Study design and infrared images of heat production in response to ADR3 signaling activation (CL) and withdrawal (CL/WD) in C57BL/6J mice. $n=12 /$ group (B) Gross and hematoxylin and eosin (H\&E) images of iWAT. (C) Iron content in iWAT and its cytosolic and mitochondrial fractions. (D) Western blot analysis of iron-handling proteins and OxPhos proteins in iWAT. (E) mRNA expression of Ucp1 and Tfr1 in iWAT. (F) Immunohistochemical (IHC) staining of TFR1 in iWAT. (G) Western blot analysis of iron-handling proteins upon cold exposure $\left(8^{\circ} \mathrm{C}\right)$ in iWAT. $n=8 /$ group. $(H)$ Electrophoretic mobility shift assay to detect the IRPs binding to the IRDye700-labeled IRE in the absence and presence of increasing dose of nonlabeled competitor IRE. $n=4$ /group. (I) RNA-seq analysis of iron-related genes in white and beige (CL treatment for 5 d) and its withdrawal for 5, 10, and 30 d using the published transcriptome datasets (ArrayExpress: E-MTAB-3978) (12). Data (log2 of FPKM values) in rows are expressed as Z-scores (mean $\pm \mathrm{SD}$ ). All data are expressed as mean $\pm \mathrm{SEM}$. In $C_{1} * * * P<0.001$ by Student's $t$ test. In $C$ and $E$, values not sharing a common letter differ significantly $(P<0.05)$ by one-way ANOVA $(a>b>c>d>e)$.

BMP-responsive elements (BREs), such as Atoh8, Smad7, and IdI (31), were also significantly down-regulated in response to $\mathrm{CL}$ (Fig. 2C). The cold treatment recapitulated the suppression of serum hepcidin levels, hepatic Hamp1 transcription (Fig. 2D), reduced phosphorylation of SMAD1/5/8 (Fig. $2 E$ ), and gene expression of Atoh8, Smad7, and IdI (Fig. 2F).

Furthermore, the reduced hepcidin upon CL stimulation increased the FPN expression in the proximal intestine (Fig. $2 G$ ). We also observed decreased FTL and increased FPN expression in the spleen, suggesting liberation of stored iron from the splenic macrophages upon ADRB3 stimulation (Fig. 2G). Accordingly, $\mathrm{CL}$ treatment significantly decreased the splenic iron content in the red pulp areas (Fig. $2 \mathrm{H}$ ). It is also notable for an increase of CD44, an early marker for erythroid upon CL stimulation (Fig. $2 G$ ), implying that ADRB3 activation may induce splenic erythropoiesis. Collectively, our results suggest that thermogenic signaling induces systemic iron mobilization by suppressing hepcidin transcription and promoting splenic iron release.

Thermogenic Stimulation Triggers Acute Hypoxia and Stress Erythropoiesis. In concert with hepcidin reduction, we observed that CL stimulation elevated serum iron and transferrin saturation. Also, hematocrit $(\mathrm{HCt})$ significantly increased in response to $\mathrm{CL}$ without altering hemoglobin $(\mathrm{Hb})$ levels and remained constant after $5 \mathrm{~d}$ of signal withdrawal (Table 1). Hence, we asked whether CL treatment is associated with systemic hypoxia and red blood cell formation. It is well established that hypoxiainducing factor $2-\alpha$ (HIF2- $\alpha$ ) is regulated by IRP1-dependent translational control; IRP1 binding to the $5^{\prime}$ UTR of Hif2- $\alpha$ mRNA represses translation in normoxia, while hypoxia leads to conformational changes of IRP1 at the expense of its IREbinding activity, allowing HIF2- $\alpha$ mRNA translation and subsequent transcriptional activation of its downstream target erythropoietin 

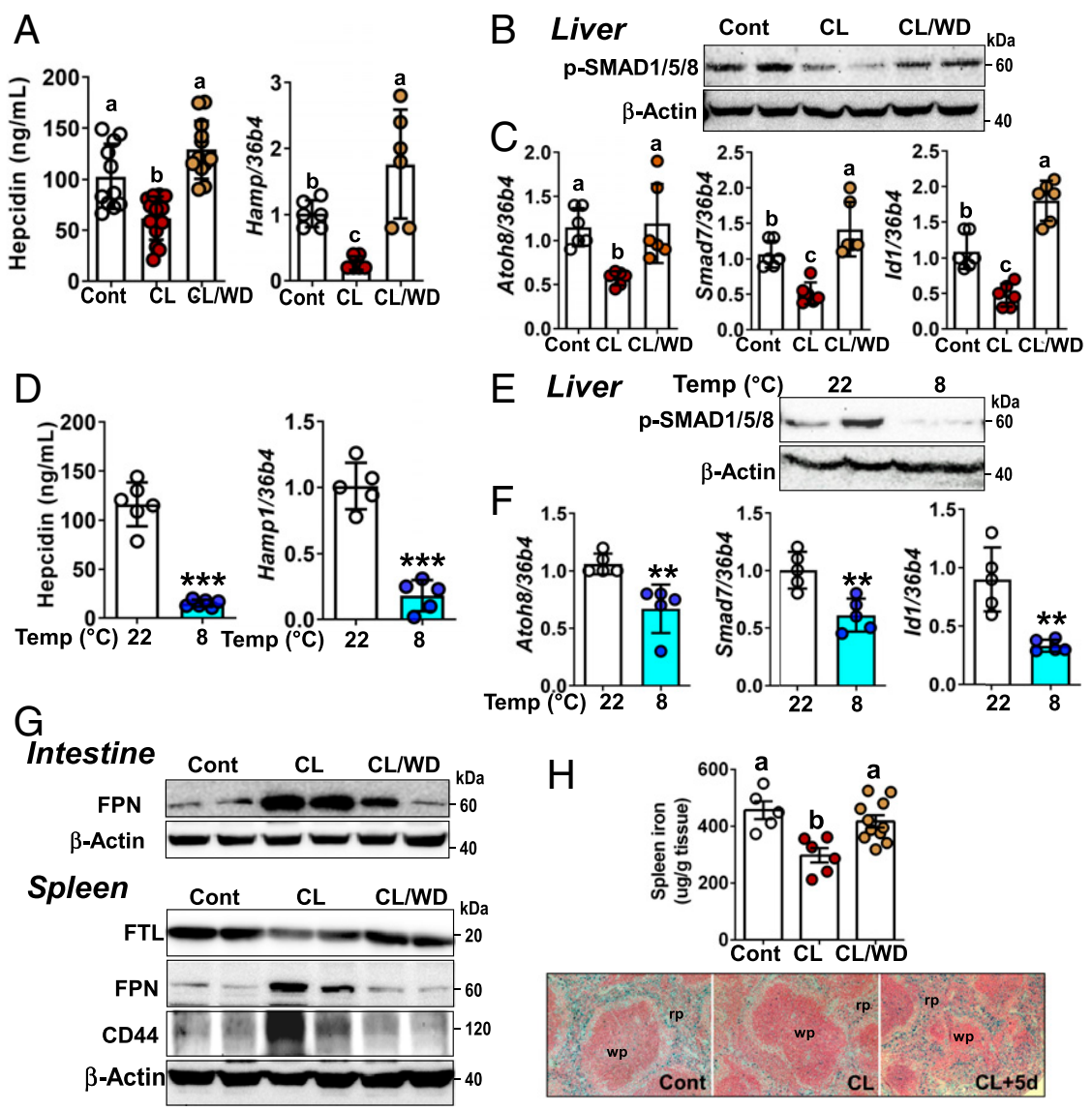

Fig. 2. Systemic iron mobilization and suppression of hepcidin. (A) Serum levels of hepcidin by ELISA and mRNA levels of hepcidin (Hamp1) in the liver upon $\mathrm{CL}$ treatment and its CLMD. (B) Hepatic SMAD signaling of p-SMAD1/5/8 upon CL stimulation. (C) mRNA expression levels containing BREs of Atoh8, Smad7, and $I d 1$ in the liver. $(D)$ Serum levels of hepcidin by ELISA $(n=8)$ and mRNA levels of Hamp1 upon cold treatment $\left(8^{\circ} \mathrm{C}\right)$. (E) Hepatic SMAD signaling p-SMAD/ 5/8 upon cold treatment. (F) mRNA expression levels containing BREs of Atoh8, Smad7, and Id1 (31) in the liver upon cold treatment. (G) Ferroportin (FPN) expression in the proximal intestine (Upper) and protein patterns of FTN, FPN, and CD44 in the spleen (Lower). (H) Iron content by ICP-MS and Perls' Prussian blue iron staining in the spleen. Data are expressed as mean \pm SEM. $n=12 /$ group for $A-C$ and $G$ and $H . n=5 \sim 6 /$ group $(D-F)$. In $A, C$, and $H$, values not sharing a common letter differ significantly $(P<0.05)$ by one-way ANOVA $(\mathrm{a}>\mathrm{b}>\mathrm{c}) . * * P<0.01, * * * P<0.001$ by Student's $t$ test to the Cont. $\beta$-actin as a loading control in all Western blot analysis.

(EPO) (32-34). Intriguingly, as early as $1 \mathrm{~h}$ after CL injection, there was an increase of serum EPO levels and acute Epo gene expression in the kidneys, a major oxygen-sensing organ in adults (Fig. 3A). Consistently, the transient increase of HIF2- $\alpha$ was detectable in the kidneys within $1 \mathrm{~h}$ after CL stimulation but not HIF1- $\alpha$ (Fig. $3 B$ ). It was also notable that von Hippel-Lindau (VHL), an E3-ligase that targets Hif2- $\alpha$, increased concomitantly with HIF2- $\alpha$ (Fig. $3 B$ ), suggesting that HIF2- $\alpha$ activation is accompanied by VHL-mediated degradation. The kidney hypoxia upon CL stimulation was further validated by an increase of protein adduct formation with a hypoxia marker pimonidazole (PIMO), which was comparable to the PIMO adduct formation at a low-oxygen environment $\left(7 \% \mathrm{O}_{2}\right)$ (Fig. $\left.3 B\right)$.
The acute increase of EPO by CL treatment was associated with global gene expression patterns of erythroblast proliferation (i.e., erythroferrone [Erfe], erythropoietin receptor [Epor], $K_{i}-67$, Cyclin $a$, and Tfr1 in the spleen) (Fig. 3C). In contrast, CL stimulation caused a minimal impact on these genes in the bone marrow, except for an increase of Erfe (Fig. 3C). Moreover, the erythroblast population (TER $119^{+} \mathrm{TFR}^{+}$) increased in the spleen, demonstrating a fivefold increase of erythroblast population upon CL stimulation for $5 \mathrm{~d}$ but no difference in the bone marrow (Fig. $3 D$ ). Acute hypoxia was also detectable in iWAT, apparently driven by HIF1- $\alpha$ but not HIF2- $\alpha$ or HIF3- $\alpha$ (Fig. $3 E$ ). It implies that adipose hypoxia may partly contribute to renal hypoxia in response to ADRB3 activation.

Table 1. Hematological parameters in response to reversible ADRB3 stimulation

\begin{tabular}{lccc} 
Parameters & Cont. $(n=8)$ & $\mathrm{CL}(n=12)$ & $\mathrm{CL} / \mathrm{WD}(n=12)$ \\
\hline Hematocrit $(\%)$ & $47.1 \pm 1.5$ & $49.7 \pm 1.9^{*}$ & $50.2 \pm 3.0^{*}$ \\
Hemoglobin $(\mathrm{g} / \mathrm{dL})$ & $12.0 \pm 0.4$ & $12.0 \pm 0.7$ & $12.32 \pm 0.8$ \\
Serum iron $(\mu \mathrm{g} / \mathrm{dL})$ & $104.17 \pm 33.4$ & $143.0 \pm 58.7 *$ & $112.7 \pm 24.0^{*}$ \\
Total iron-binding capacity $(\mu \mathrm{g} / \mathrm{dL})$ & $259.33 \pm 43,6$ & $287.1 \pm 61.5$ & $274.9 \pm 34.3$ \\
Transferrin saturation $(\%)$ & $37.52 \pm 7.6$ & $45.7 \pm 9.5^{*}$ & $43.27 \pm 6.6^{*}$ \\
\hline
\end{tabular}

${ }^{*} P<0.05$ by Student's $t$ test. 

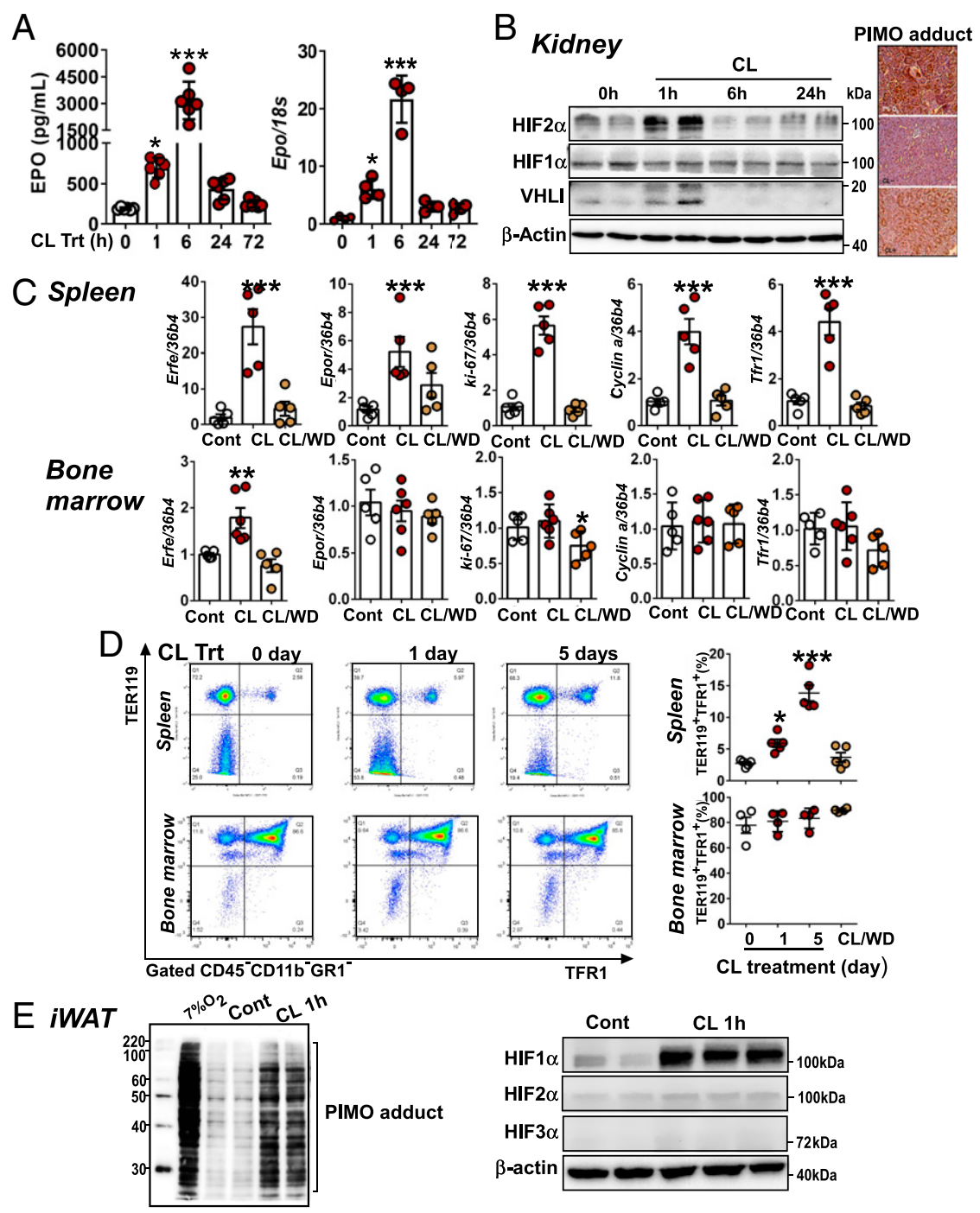

Fig. 3. Acute hypoxia, EPO production, and stress erythropoiesis. C57BL/6J mice were stimulated with CL and killed at the given time. (A) Kinetic changes of serum levels of EPO and mRNA levels of Epo in the kidneys. (B) Kinetic changes of hypoxia-related protein expression and immunohistochemical staining of protein adducts with a hypoxia marker pimonidazole (PIMO) in the kidneys. (C) mRNA expression related to erythroid differentiation, Erfe, Epor, $K_{i}-67, C^{2}{ }^{2}$ clin $a$, and Tfr1 in the spleen (Upper) and bone marrow (Lower). (D) Flow cytometric analysis of erythroid progenitor cells (TER119+TFR $1^{+}$) in the spleen. A representative flow cytogram (Left) and average values (Right). (E) PIMO-protein adduct formation by Western blot analysis at post-1-h CL treatment (Left) and HIFs isomer expression in the iWAT. Data are expressed as mean \pm SEM. $n=5 /$ group/time point. ${ }^{*} P<0.05$; ${ }^{* *} P<0.01$; ${ }^{* *} P<0.001$ to the Cont. by oneway ANOVA.

Taken together, these results suggest that ADRB3 stimulation by $\mathrm{CL}$ induces 1 ) acute hypoxia, HIF2- $\alpha$ activation, and erythropoietin production in the kidneys and 2) stress erythropoiesis in the spleen, but not in the bone marrow, contributing to hepcidin down-regulation and systemic iron mobilization.

Inhibition of HIF2- $\alpha$ Interfered with Beige Fat Development. To determine the contribution of acute hypoxia and HIF2- $\alpha$ activation to beige fat development, we used a pharmacological HIF2- $\alpha$ inhibitor. PT2385 (PT) functions as a HIF2- $\alpha$-specific inhibitor by disrupting HIF2- $\alpha$ heterodimerization and subsequently inhibiting HIF2- $\alpha$ target gene expression (35). Mice received CL alone or CT injection plus oral administration of $\mathrm{PT}$ (Fig. $4 A$ ). The mice with CL+PT showed significantly reduced heat release (Fig. 4B) and blunted EPO release in the kidneys (Fig. $4 B$ ) compared with CT-only mice. Besides, PT treatment almost completely abolished the CL-mediated up-regulation of TFR1 (Fig. 4D), induction of gene expression related to erythroblast proliferation (i.e., Erfe,
Epor, $K_{i}-67$, Cyclin $a$, and Tfr1) in the spleen (Fig. 4E) and downregulated Hamp1 expression in the liver (Fig. $4 F$ ). Also, HIF2- $\alpha$ inhibition by PT substantially impeded the development of beige fat-specific multilocular morphology (Fig. 4G), UCP1 expression, and IRP/IRE signaling-mediated protein responses (i.e., IRP2, TFR1, Cytc, and FTL) and OxPhos proteins (Fig. 4H). Furthermore, PT treatment dampened the CL-mediated increase of iron content in the iWAT (Fig. 4I). These results strongly support an iron-regulatory network in which ADRB3-induced beige fat development coupled with HIF2- $\alpha$ induced hypoxia signaling and subsequent iron mobilization.

Blockage of Iron Mobilization by Hep25 Diminished CL-Induced Beige Fat Development. We next investigated the contribution of hepcidin down-regulation and systemic iron mobilization to beige fat development by injecting mice with human hepcidin-25 peptides ( $h$ Hep25) along with CL. The cotreatment with $\mathrm{CL}$ and $h$ Hep 25 remarkably reduced thermogenesis (Fig. 5A). As expected, CL-induced iron 
A

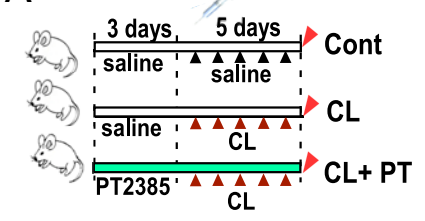

B

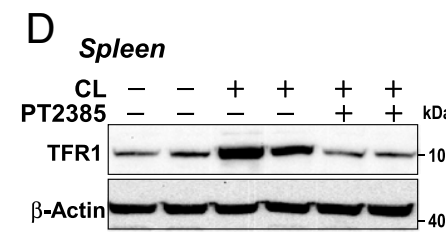

G

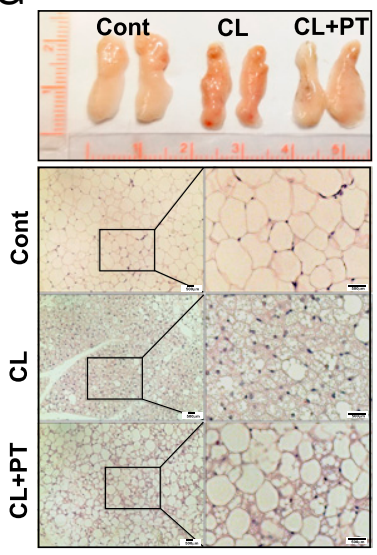

E

H
B
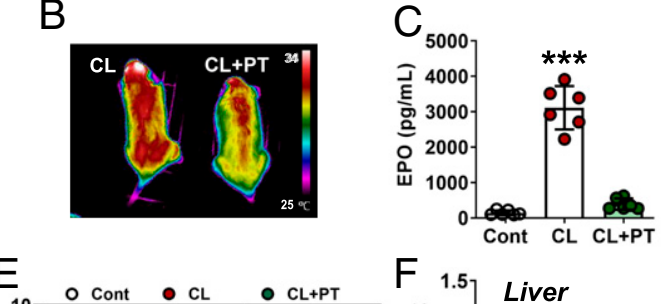$$
\text { F }
$$
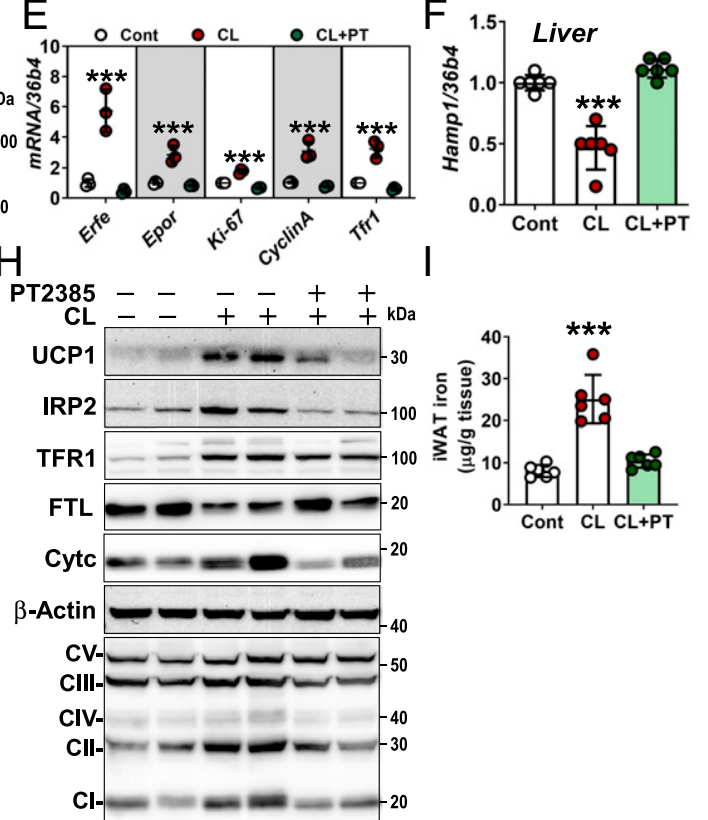

Fig. 4. Effects of chemical inhibition of HIF2- $\alpha$ on beige fat development. (A) Experimental design. C57BL/6J mice were gavaged with either saline or PT2385 (PT), a HIF2- $\alpha$-specific inhibitor. $n=8$ /group. $(B)$ Thermogram in mice with $\mathrm{CL}$ alone or $\mathrm{CL}+\mathrm{PT}$ administration. (C) Serum EPO levels after 6-h CL injection. (D) Protein patterns of TFR1 in the spleen. $(E)$ mRNA expression levels related to erythroid differentiation, Erfe, Epor, $K_{i}-67, C y c l i n A$, and $T f r 1$ in the spleen. $(F)$ mRNA levels of Hamp1 in the liver. $(G)$ Gross images of iWAT (Upper) and H\&E images of iWAT (Lower). (H) Protein expression pattern of iron-regulatory and OxPhos proteins in the iWAT. (I) Iron content in the iWAT. Data are expressed as mean \pm SEM. ${ }^{* *} P<0.001$ to the Cont. by one-way ANOVA.

mobilization was dampened by the simultaneous injection with $h \mathrm{Hep} 25$, resulting in reduced serum iron, $\mathrm{Hb}$ level, $\mathrm{HCt}$, and transferrin saturation (Fig. $5 B$ ). In addition, the blockage of iron mobilization by $h$ Hep 25 caused a substantial reduction in ADRB3-mediated 1) iron accumulation in the iWAT (Fig. 5C), 2) UCP1 up-regulation, IRP/IRE signaling responses, and beige adipocyte-specific multilocular morphology in the iWAT (Fig. $5 D$ ), and 3) beige-specific mRNA profiles including Ucp1, Cidea, and Tfrl (Fig. 5E) compared to CL treatment alone. Collectively, these results demonstrated that hepcidin down-regulation in response to $\mathrm{CL}$ treatment is a prerequisite for maximum beige adipogenesis and adaptive heat production.

\section{Discussion}

Activating ADRB3 either by chemical agonists or exposure to cold temperature is a common but robust way to elicit adaptive thermogenesis. Here, we focused on revealing the adaptation of iron metabolism in this process. ADRB3 stimulation induces two distinct but coordinated iron-regulatory pathways; one pathway creates an intracellular iron gradient to implement IRP binding to IRE in adipocytes (Fig. 1), and the other pathway elicits acute hypoxia to liberate stored iron into circulation (Figs. 2-5). Based on these results, we propose our working model that modulation of iron metabolism is a fundamental mechanism underlying beige fat development; ADRB3 stimulation promotes beige adipogenesis, an iron-demanding process that leads to activation of the IRP/IRE signaling pathway. In turn, iron acquisition of beige adipocytes is facilitated by multiorgan-involved systemic iron mobilization through acute hypoxia (kidneys), stress erythropoiesis (spleen), and hepcidin down-regulation (liver) (Fig. 6).

The modification of iron metabolism in adipose tissue is linked with endocrine functions. The serum ferritin and transferrin levels are inversely associated with adiponectin and insulin sensitivity in humans $(36,37)$. Also, adipocyte iron status alters leptin secretion by regulating cAMP-response element-binding protein $(38,39)$. However, IRP regulation and iron homeostasis in adipocytes are not fully understood yet. An earlier study by Festa et al. demonstrated that IRP1 is vital for white adipogenesis by acting primarily as a cytosolic aconitase (40). The importance of IRP1 in white adipocyte formation was also confirmed in the lentiviral deletion of Irp1 (41). Recently, two studies by Li et al. and Qiu et al. highlighted the significance of adipocyte iron uptake for thermogenic fat development using the animal model of adipocytespecific deletion of TFR1 $(28,42) . T f r 1^{-1-}$ in adipocytes significantly impaired the mitochondrial development in brown and beige adipose tissue and abolished thermogenic function $(28,42)$. Recently, we reported the cell-autonomous regulation of the IRP/ IRE system in adipocytes dependent on depot specificity, demonstrating that IRP binding activity to IRE increases proportionally to the thermogenic activity of adipocytes (i.e., brown $>$ beige $>$ white adipose tissue) to secure iron required for mitochondrial biogenesis (6). Gabrielsen et al. reported that deletion of the adipocyte FPN, an iron exporter, resulted in adipocyte iron loading and insulin resistance (37). In contrast, Britton et al. revealed that FPN does not play a significant role in maintaining adipocyte iron homeostasis (43). During thermogenic conversion, FPN levels are increased upon CL treatment and decreased by CL 

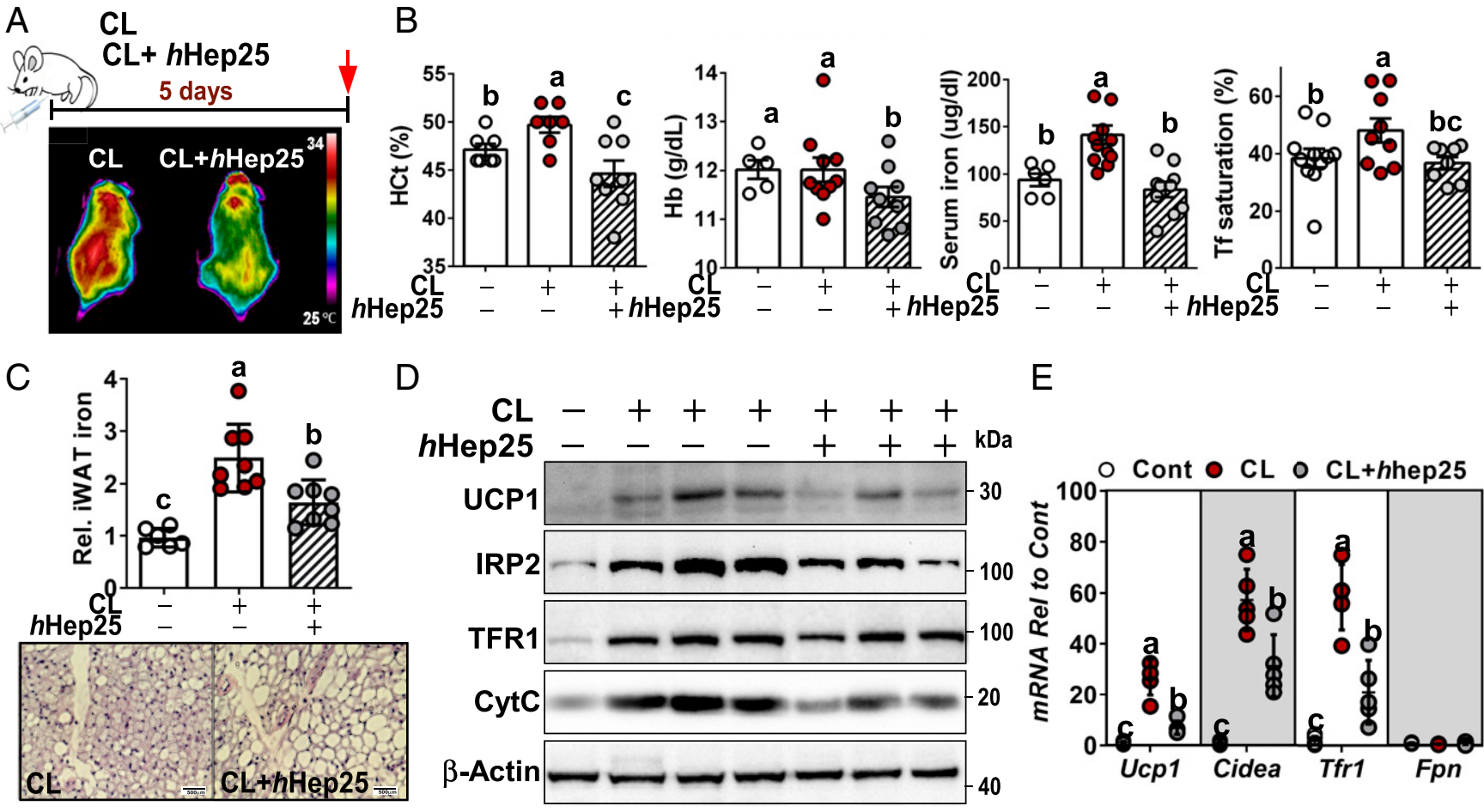

E

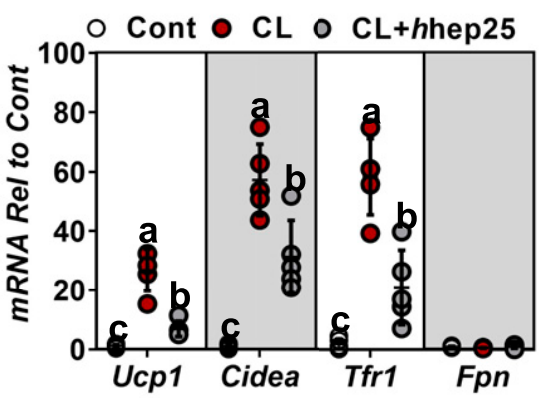

Fig. 5. Effects of exogenous hepcidin injection on beige fat development. (A) Experimental design. $h H$ Hep25 was injected simultaneously with ADRB3 agonist $\mathrm{CL}$ (Upper). Thermogram in mice with $\mathrm{CL}$ alone and $\mathrm{CL}+h \mathrm{Hep} 25$ administration (Lower). (B) Hematological factors. (C) Iron content of the iWAT (Upper) and H\&E staining of iWAT (Lower). (D) Protein expression patterns of UCP1, IRP2, TFR1, and CytC in the iWAT. (E) mRNA levels of Ucp1, Cidea, Tfr1, and Fpn. Data are expressed as mean \pm SEM. In all experiments, $n=10$ /group. Values not sharing a common letter differ significantly $(P<0.05)$ by one-way ANOVA $(a>b>c)$.

withdrawal (Fig. 1D). Considering that FPN has IRE in the 5' UTR, posttranscriptional FPN down-regulation is overridden by reduced hepcidin levels in the liver (Fig. $2 A$ ) and iWAT (SI Appendix, Fig. 2).

This study demonstrates the augmented IRP/IRE binding affinity in beige fat upon ADRB3 activation. We revealed that IRP2 is a high-fidelity biomarker for thermogenic fat. The accumulation of IRP2 is concurrent with an increase of UCP1 and proportional to thermogenic capacity in iWAT regardless of ADRB3 signal types (cold temperature versus CL injection) (Fig. 1). In contrast, IRP1 accumulation was only detectable in CL-driven but not in coldinduced adipose browning. The inconsistent IRP1 up-regulation may arise from heterogeneous mechanisms of adipocyte browning; ADRB3 activation promotes de novo adipogenesis from beige precursor cells, increasing both IPR1 and IRP2 expression (6). On the other hand, ADRB3 activation could induce a functional switch of existing white adipocytes into beige (white-to-beige conversion). In the latter case, conversion of IRP1 from cytosolic aconitase to RNA-binding protein is controlled by conformational changes without a noticeable increase of IPR1 (16). Thus, IPR1 regulation during iWAT browning seems to be regulated by the magnitude of ADRB3 stress rather than its type (i.e., chemical agonist versus cold exposure), although this speculation requires further research to define the exact mode of IRP1 and IRP2 regulation during thermogenesis.

It was not surprising to find that genetic ablation of either Irp1 or Irp2 impaired beige fat development, since IRP2 cannot fully compensate for brown adipose tissue (BAT) iron metabolism in $\operatorname{Irp} 1^{-/-}$mice and, vice versa, in $\operatorname{Irp} 2^{-/-}$mice (44). A large body of literature suggests that IRP2 is responsible for regulating iron homeostasis at the cellular level (45), while IRP1 is in charge of erythropoiesis $(32,33,46)$. These studies appear to support our proposed model (Fig. 6), wherein we emphasize the coordination of iron-regulatory pathways between cell-autonomous IRP/IRE binding activity in adipocytes and systemic oxygen sensing, necessitating both IRP1 and IRP2. Although insightful, our working model has some inevitable limitations, since it is framed based on $\operatorname{Irp} 1^{-/-}$and Irp $2^{-/-}$mice (SI Appendix, Fig. 1), and it is difficult to tease out the confounding effects of whole-body IRP1 or IRP2 deficiency from the distinctive tissue-specific roles. Future studies using the adipocyte-specific IRP knockout mice are indispensable for elucidating the contribution of adipocyte IRPs to thermogenic fat development.

Liver cells are absent of ADRB3 and are thus unable to respond to ADRB3 signaling. In line with this notion, we confirmed that CL treatment posed no impact on Hamp1 expression levels in HepG2 cells, while dibutyl cAMP, a cell-permeable cAMP analog, significantly increased Hamp1 gene expression (SI Appendix, Fig. $3 A$ ). Therefore, CL-induced hepcidin down-regulation must be indirect and intertwined with other tissue that could possess ADRB3, such as adipocytes or red blood cells (47). In this study, we presume that the origin of the hypoxia response upon $\mathrm{CL}$ treatment would be adipose tissue (Fig. 4). It has been shown that CL treatment increased the oxygen consumption rate twofold within $10 \mathrm{~min}$ (26). In the hypoxia-sensing mouse model, Kim et al. demonstrated that thermogenic activation increased hypoxia reporter activities in the BAT and iWAT (27). Li et al. recently reported that thermogenic fat-specific deletion of Hif1- $\alpha$ abolished the beige fat development (28). In the present study, we observed HIF1- $\alpha$ stabilization and accumulation of pimonidazole-protein adduct in iWAT (Fig. 3E) concomitant with kidney hypoxia (Fig. $3 B$ ) within $1 \mathrm{~h}$ post-CL treatment. Taken together, we propose that ADRB3-induced acute hypoxia in the iWAT is sensed by the kidneys, triggering the HIF2- $\alpha$-mediated systemic hypoxic responses for erythropoiesis. 


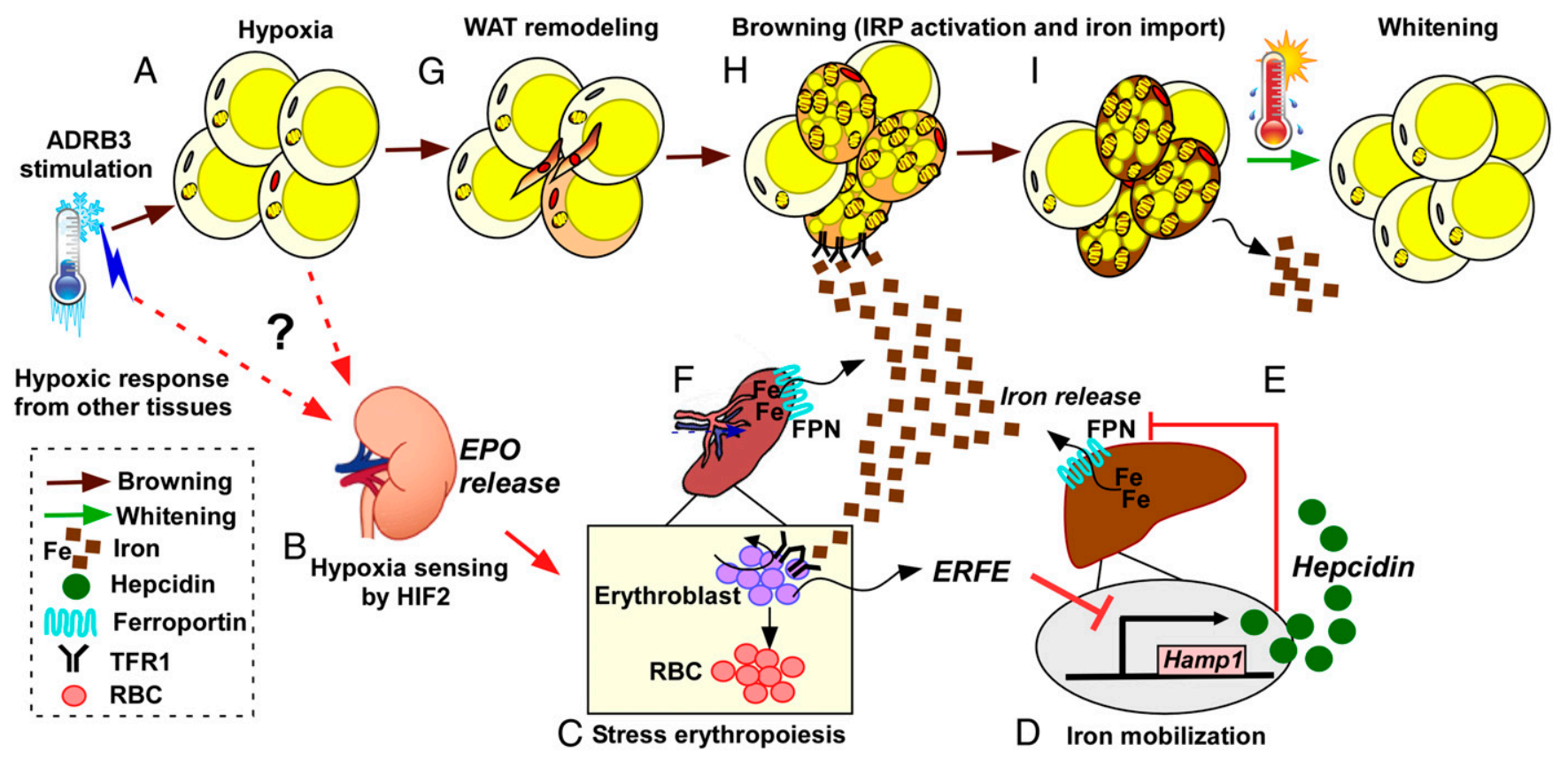

Fig. 6. Proposed working model: A feedforward iron-regulatory network for beige adipogenesis. (A) ADRB3 activation triggers two divergent ironregulatory signals, one for intracellular iron regulation in adipocytes (brown arrows) and the other for systemic hypoxia in an adipocyte-dependent and/or -independent manner (red arrows). (B) ADBR3 activation lowers $\mathrm{pO}_{2}$ inducing EPO production in the kidneys. (C) EPO promotes stress erythropoiesis in the spleen, and proliferating erythroblast secretes ERFE. $(D)$ ERFE suppresses the hepcidin production in the liver. ( $E$ and $F$ ) The reduced hepcidin facilitates iron release from the liver and spleen by protecting FPN from degradation. In turn, (G) ADRB3 stimulation promotes proliferation and differentiation of beige progenitor cells. $(H)$ Beige differentiation induces cell-autonomous IRP activation, promoting TFR1-dependent iron import. (I) Consequently, liberated iron from storage (i.e., the liver and spleen) is redistributed to beige adipocytes for mitochondrial biogenesis. After the withdrawal of the ADRB3 signal, beige adipocytes turn to white adipocytes by reducing intracellular iron content (blue arrow).

At the cellular level, we should consider the possibility that thermogenic adipose tissue develops pseudohypoxia. In normoxia conditions, HIF1- $\alpha$ undergoes prolyl hydroxylation by prolyl hydroxylase (PHD), which requires oxygen $\left(\mathrm{O}_{2}\right)$, ferric iron $\left(\mathrm{Fe}^{3+}\right)$, and 2-oxoglutarate (2-OG). The hydroxylation of HIF1- $\alpha$ leads to interaction with VHL and rapid proteasomal degradation of HIF1- $\alpha$ (48). Under low iron concentrations, hypoxic conditions, or increased mitochondrial reactive oxygen species (ROS), the HIF1- $\alpha$ subunit is no longer hydroxylated and is therefore stabilized. Notably, beige adipogenesis is associated with distinctive iron-deficient responses (Fig. $1 D-F$ ), and RNA sequencing (RNA-seq) analysis reveals that beige thermogenesis is associated with reduced $V h l$ expression (Fig. 1I), which could suppress PHDdependent HIF1- $\alpha$ degradation. Besides, accumulating evidence supports that mitochondrial ROS production is a critical mechanism for UCP1-dependent thermogenesis in adipocytes $(26,49)$. Through the ADRB3-mediated adaptive responses of cytosolic iron deprivation and mitochondrial ROS production, adipocytes seem to induce a pseudohypoxic state, leading to HIF1- $\alpha$ stabilization regardless of oxygen levels. Irrespective of the nature of iWAT hypoxia upon ADRB3 stimulation, HIF2- $\alpha$-dependent hypoxic responses in the kidneys seem to be required for maximal beige fat development (Fig. 4).

Until now, it remains unknown how ADRB3 activation triggers the central hypoxic responses and subsequent erythropoiesis. The weakest link of our current working model is that we cannot provide direct evidence linking renal hypoxia with iWAT hypoxia. García-Martín et al. showed that adipose-specific deletion of HIF2- $\alpha$ interferes with brown thermogenesis (50). With this study, we cannot completely exclude the possibility that our study design with the HIF2- $\alpha$ inhibitor (Fig. 4) is insufficient to provide the link between renal hypoxia and iWAT browning. In addition, there is a likelihood that ADRB3 affects cardiac contraction or vasocontraction, contributing to systemic hypoxia. Given this mechanistic pitfall, our working model leaves room to determine whether renal hypoxia may occur as an iWAT-dependent and/or -independent mechanism (Fig. 6). In addition, there is a research gap regarding the temporal correlation between blood oxygen tension $\left(\mathrm{pO}_{2}\right)$, EPO production, and HIF1- $\alpha$ activation in thermogenic fats in response to ADRB3 activation.

It has long been a mystery how oxygen sensing and EPO production can cause hepcidin down-regulation because EPO treatment failed to suppress hepcidin expression in hepatocytes (51). Kautz et al. discovered that ERFE from erythroblasts is the essential ligand that mediates hepcidin repression $(52,53)$. The recent study by Arezes et al. also supported the idea that ERFE suppresses hepcidin by inhibiting hepatic BMP/SMAD signaling (54). Upon ADRB3 stimulation, we observed the canonical signaling pathways for erythropoiesis, an increased ERFE-expressing erythroblast population, inhibition of SMAD1/5/8 phosphorylation, and hepcidin down-regulation (Figs. 2 and 3). Unfortunately, our effort to detect ERFE expression in serum was unsuccessful. Our alternative approach was to incubate the CL- or cold-treated serum with hepatocyte cultures. The CL-stimulated serum significantly reduced Hamp1 gene expression in HepG2 cells compared to control serum (SI Appendix, Fig. 3B), suggesting that hepcidinreducing factor is released into serum as a consequence of ADRB3 activation. Our remaining questions regarding stress erythropoiesis (55) and ERFE production during thermogenesis could be addressed by using the animal model of Erfe deletion or ERFE neutralization. More importantly, it remains unknown whether the same signaling interplay we identified in rodents would exist in humans. Stoffel et al. reported that central obesity in healthy women is linked with high serum levels of inflammatory cytokines and hepcidin (56), suggesting that central obesity may attribute to reduced beige thermogenesis as the high levels of hepcidin inhibit iron mobilization and redistribution required for beige conversion. Another insight comes from cryogenic therapy, 
which involves exposure to extreme cold vapor for a short duration (57). Cryogenic therapy reduces fat mass due to augmented thermogenic energy loss from the subcutaneous fat, a coldinduced thermogenic process (58). Interestingly enough, cryogenic therapy is associated with reduced hepcidin levels (59), suggesting a similar signaling association between iron mobilization and adaptive thermogenesis in humans.

Here, we identified an iron-regulatory network that underlies beige thermogenesis, a hitherto underinvestigated aspect of beige fat physiology. Numerous epidemiological studies revealed that iron dyshomeostasis and iron deficiency anemia are prevalent in obese individuals, partly due to inflammation and aberrant hepcidin production (60-64). Our work suggests that dysregulation of iron homeostasis in obesity may be attributed to defective beige thermogenesis, precipitating obesity-mediated metabolic complications. In supporting this concept, we recently demonstrated that dietary iron deficiency exacerbates high-fat diet-induced obesity partly due to lack of thermogenic function (65). In summary, our work offers a conceptual framework for a better understanding of beige fat physiology. The association between beige fat development and iron/oxygen metabolism would provide a unique therapeutic opportunity to enhance beige thermogenesis otherwise compromised in obesity and iron deficiency.

\section{Materials and Methods}

Animals. All animal protocols are approved by the Institutional Animal Care and Use Committee of the University of Nebraska-Lincoln and the University of Massachusetts Amherst. C57BL/6J male mice (6 wk old) were purchased from the Jackson Laboratory. Mice with genetic ablation on Irp1 and 2 $\left(I r p 1^{-/-}\right.$and $I r p 2^{-/-}$) were provided by. Tracey Rouault (Section on Human Iron Metabolism, National Institute of Child Health and Human Development, Bethesda, Maryland) (66). For thermogenic activation, mice ( $n=$ 12/group) were intraperitoneally injected with saline or $\mathrm{CL}$ (Santa Cruz Biotechnology, $1 \mathrm{mg} /$ kilogram bodyweight), a ADRB3-specific agonist, for 5 d. For withdrawal of ADRB3 signaling, $5 \mathrm{~d} C L$ injection was followed by an additional $5 \mathrm{~d}$ of saline injection before killing (Fig. $1 \mathrm{~A}$ ). For cold treatment, mice were housed at either ambient temperature $\left(22^{\circ} \mathrm{C}\right)$ or $8^{\circ} \mathrm{C}$ in a rodent chamber (Powers Scientific, Inc) for 2 wk. For the HIF2- $\alpha$ inhibitor study, mice were orally administered daily with either vehicle or PT2385 (MedChem $50 \mathrm{mg} /$ kilogram BW) from $3 \mathrm{~d}$ before $\mathrm{CL}$ injection and throughout the $5 \mathrm{~d}$ of $\mathrm{CL}$ treatment. For the HIF2- $\alpha$ inhibitor study, PT2385, purchased from Med Chem Express, was suspended in saline with $0.5 \%$ sodium carboxymethyl cellulose, $2.5 \%$ Tween 80 , and $2.5 \%$ dimethyl sulfoxide. (Fig. 4A). For the hepcidin study, mice ( $n=9$ /group) were administered with $h$ Hep25 (Sigma SML1118, $20 \mu \mathrm{g} / \mathrm{d} / \mathrm{mouse}$ ) simultaneously with $\mathrm{CL}$ daily for $5 \mathrm{~d}$ (Fig. $5 A$ ). Fo the detection of heat release, we used an IR camera (A655sc, FLIR Systems), as we described previously (67). At necropsy, each mouse was fully perfused with $25 \mathrm{~mL}$ ice-cold saline to remove the residual blood to avoid the potential contamination of iron from the blood. For the collection of the intestine sample, the first one-fourth of the proximal intestine from the stomach was used for analysis.

Measurement of Hypoxia. For hypoxia measurement, C57BL/6 mice were in jected with $60 \mathrm{mg} / \mathrm{kilogram} \mathrm{BW}$ of pimonidazole (Hypoxyprobe), a hypoxiasensitive dye, to form stable protein adducts, along with $\mathrm{CL}(1 \mathrm{mg} / \mathrm{kg} \mathrm{BW})$ After $1 \mathrm{~h}$ of intraperitoneal injection, mice were euthanized to harvest the kidneys and iWAT. Hypoxia-induced pimonidazole-protein adducts were either determined by immunohistochemistry in the kidney sections or Western blot analysis in the iWAT. Hypoxyprobe Plus Kit (Hypoxyprobe) was used for fluorescein isothiocyanate (FITC)-conjugated to anti-pimonidazole mouse IgG1 monoclonal antibody (FITC-MAb1) and rabbit anti-FITC conjugated with horseradish peroxidase as a secondary reagent according to the manufacturer's guide and published protocol (68).

IRP/IRE Binding by EMSA. EMSA for IRP/IRE binding was performed based on the published protocol (69) with the following modification. The cytosolic fractions were prepared from the tissue (iWAT and liver). A total of $2 \mu \mathrm{g}$ of cytosolic protein was incubated with $16 \mu \mathrm{L}$ reaction mixture containing $5 \%$ glycerol, 0.2 units Super RNasin (Promega, N2511), $2 \mu \mathrm{g}$ of yeast transfer RNA (tRNA, Thermo Fisher Scientific, AM7119), $50 \mu \mathrm{M}$ dithiothreitol (DTT), and 50 nM IRDye700-IRE consensus RNA oligonucleotides in $10 \mathrm{mM}$ Tris. $\mathrm{HCl}(\mathrm{pH} 7.5)$, $10 \mathrm{mM} \mathrm{MgCl}$, and $100 \mathrm{mM} \mathrm{KCl}$ for $30 \mathrm{~min}$ at room temperature. The resulting reaction mixture was mixed with $2 \mu \mathrm{L}$ Orange loading dye (Li-Cor, P/N 927-10100), loaded on either 10\% Novex ${ }^{\mathrm{TM}}$ TBE gel (Invitrogen), and run at $100 \mathrm{~V}$ for $1 \mathrm{~h}$ in the dark. For separation of IRPs/IRE, cytosolic proteins were loaded on 4 to $12 \%$ acrylamide/TBE gel (Invitrogen) and run at $120 \mathrm{~V}$ for $3 \mathrm{~h}$ in the dark. The gel was scanned using the Odyssey CLX System (Li-Cor). The RNA oligonucleotide consensus to IRE labeled with IRDye700 probe was synthesized from Integrated DNA Technology based on the published sequence 5'-UCCUGCUUCAACAGUGCUUGGACGGAAC-3' (70).

RNA-Seq Analysis. For analysis of transcriptomic changes of iron metabolismrelated genes, we used the published transcriptome datasets during the white-to-beige transition (ArrayExpress: E-MTAB-3978) (12). Published candidate genes known to be involved in iron metabolism (111 genes) were adopted for RNA-seq analysis (71). FastQC software (Andrews, 2010) was used to check the quality of paired-end RNA-seq data (available online at: http://www.bioinformatics.babraham.ac.uk/projects/fastqd/). All the bases with a quality score less than 20 were removed. After removing low-quality bases, sequences with at least $50 \%$ of read length were retained. After preprocessing, each file contained at least $\sim 20$ million reads. We used GRCm38/ MM10 genome assembly as a reference that was indexed using the Bowtie 2 tool (72). Next, the preprocessed reads were mapped on the reference using the TopHat tool (73). This process aligned with reads and identified splice junctions between exons. The inner distance between mate pairs $(=150)$ with SD $(=50)$ was used (obtained from library preparation data we submitted). For the gene expression analysis, the tool CuffLinks was used to calculate fragment per kilobase per million mapped reads (FPKM) (SI Appendix, Fig. 1). For further analysis, FPKM values were log (base $=2$ ) transformed (SI Appendix, Table S1). The heatmap was generated using Log 2 transformed FPKM values in the gplots package in R. In the heatmap, for better visualization between samples, the data in rows were scaled (using Z-score, mean $=0$ and SD $=1$ ).

Measurement of Iron by Inductively Coupled Plasma Mass Spectrometry. For iron measurement, the tissue samples were fully perfused by saline, digested in $70 \%$ nitric acid for $2 \mathrm{~h}$ at $75^{\circ} \mathrm{C}$, and diluted with distilled water. Inductively coupled plasma mass spectrometry (ICP-MS, NexION 300X; PerkinElmer) was used to determine total iron content in tissue samples of white and brown adipose tissue, liver, spleen, and serum. A commercial kit was used to obtain the mitochondria and cytosol fractionation (Abcam ab65320) before measuring the cytosolic and mitochondrial iron by ICP-MS. Nonheme iron levels were determined according to the published protocol (74). The tissue samples were digested by acid hydrolysis in a $95^{\circ} \mathrm{C}$ water bath for $2 \mathrm{~h}$ followed by centrifugation. The concentration of nonheme iron was determined by subsequent reaction with bathophenanthroline reagent, and absorbance was measured at $540 \mathrm{~nm}$. Data were normalized by the tissue weight, and heme iron levels were calculated by subtracting nonheme iron levels from total iron levels.

Hematological Analyses and Enzyme-Linked Immunoassay (ELISA). For the measurement of $\mathrm{HCt}$, the heparinized-whole blood was transferred to a microhematocrit capillary tube (LW Scientific, CNT-ZPC7-40HE), and the red blood cells were separated using the $\mathrm{HCt}$ centrifuge at $12,000 \mathrm{rpm} \times 3 \mathrm{~min}$. After centrifugation, the separation line was measured with a microhematocrit reader card (LW Scientific). Hb levels were quantified in the whole blood using an $\mathrm{Hb}$ colorimetric assay kit purchased from Cayman. Hepcidin levels were measured by using the Hepcidin Murine-Compete ELISA Kit from Intrinsic Lifesciences (HMC-001). Serum EPO levels were measured by using a commercial mouse EPO ELISA kit (R\&D Systems, DY959).

Flow Cytometric Analysis of Erythroid Precursors. For bone marrow single-cell preparation, cells from mice tibia and femurs were flushed, as we prepared previously. The preparation of single cells from the spleen was prepared by mechanical disintegration using a cell strainer. The staining of cells and flow cytometric analysis followed the published procedures (75) with the following antibodies: eFlore450, APC-Cy7-CD45, APC-Cy7-CD11b, APC-Cy7-Gr1, FITC-TFR1, and PE-TER119 (eBioscience). For the gating procedure, dead cells were gated out using eFlore450 as a marker. Among live cells, leukocytes, monocytes, and granulocytes were gated out using APC-Cy7-conjugated CD45, CD11b, and GR1 as markers, respectively. The CD45- CD11b-GR1 ${ }^{-}$ cells were gated using forward and side scatters characteristics for erythroblast (TER $119^{+}$TFR $1^{+}$) based on at least 10,000 events using a DxP10 flow cytometer (Cytek).

Immunohistochemistry of TFR1. Inguinal adipose tissue was fixed with $10 \%$ buffered formalin. The $5-\mu \mathrm{m}$ sections were deparaffinized and rehydrated through graded alcohols, and antigen retrieval was performed using citrate 
buffer $\mathrm{pH}$ 6.0. The sections were incubated in $3 \% \mathrm{H}_{2} \mathrm{O}_{2}$ to reduce endogenous peroxidase activity and were blocked with goat serum. Incubation with TFR1 antibody (1:250 from Cell Signaling) was performed overnight at $4{ }^{\circ} \mathrm{C}$, followed by a biotin-conjugated secondary antibody (Dako) for $1 \mathrm{~h}$ at room temperature. HRP was detected by DAB (Amresco).

qPCR. Total RNA was extracted using TRIzol reagent (Life Technologies), and $1 \mu \mathrm{g}$ RNA was reverse transcribed by iscript (Biorad) as described previously (76). Gene expression was determined by RT-qPCR (Quant Studio 6 Flex RealTime PCR, Applied Biosystems) using SYBR green (Thermo Fisher Scientific), and relative gene expression was determined based on the $2^{-\Delta \Delta C T}$ method with normalization of the raw data to $36 \mathrm{~b} 4$. All primer sequences are available in SI Appendix, Table S2.

Western Blot Analysis. Protein lysates for all Western blots were obtained using radioimmunoprecipitation assay (RIPA) buffer and performed as described previously using either 8 or $10 \%$ sodium dodecyl sulfate (SDS) gels (67). Chemiluminescence from enhanced chemiluminescent (ECL) solution (Western Lightning) was detected using an Odyssey FC Imaging System

1. B. Cannon, J. Nedergaard, Brown adipose tissue: Function and physiological significance. Physiol. Rev. 84, 277-359 (2004).

2. A. M. Cypess et al., Identification and importance of brown adipose tissue in adult humans. N. Engl. J. Med. 360, 1509-1517 (2009).

3. W. D. van Marken Lichtenbelt et al., Cold-activated brown adipose tissue in healthy men. N. Engl. J. Med. 360, 1500-1508 (2009).

4. M. Saito et al., High incidence of metabolically active brown adipose tissue in healthy adult humans: Effects of cold exposure and adiposity. Diabetes 58, 1526-1531 (2009).

5. L. Sidossis, S. Kajimura, Brown and beige fat in humans: Thermogenic adipocytes that control energy and glucose homeostasis. J. Clin. Invest. 125, 478-486 (2015).

6. J. S. Yook et al., The thermogenic characteristics of adipocytes are dependent on the regulation of iron homeostasis. J. Biol. Chem. 296, 100452 (2021).

7. F. Forner et al., Proteome differences between brown and white fat mitochondria reveal specialized metabolic functions. Cell Metab. 10, 324-335 (2009).

8. K. Ikeda, P. Maretich, S. Kajimura, The common and distinct features of brown and beige adipocytes. Trends Endocrinol. Metab. 29, 191-200 (2018).

9. T. A. Rouault, N. Maio, Biogenesis and functions of mammalian iron-sulfur proteins in the regulation of iron homeostasis and pivotal metabolic pathways. J. Biol. Chem. 292, 12744-12753 (2017)

10. M. T. Boniecki, S. A. Freibert, U. Mühlenhoff, R. Lill, M. Cygler, Structure and functional dynamics of the mitochondrial Fe/S cluster synthesis complex. Nat. Commun. 8 , 1287 (2017)

11. M. Cedikova et al., Mitochondria in white, brown, and beige adipocytes. Stem Cells Int. 2016, 6067349 (2016).

12. S. Altshuler-Keylin et al., Beige adipocyte maintenance is regulated by autophagyinduced mitochondrial clearance. Cell Metab. 24, 402-419 (2016).

13. J. W. Rensvold et al., Complementary RNA and protein profiling identifies iron as a key regulator of mitochondrial biogenesis. Cell Rep. 3, 237-245 (2013).

14. J. W. Rensvold, K. A. Krautkramer, J. A. Dowell, J. M. Denu, D. J. Pagliarini, Iron deprivation induces transcriptional regulation of mitochondrial biogenesis. J. Biol. Chem. 291, 20827-20837 (2016).

15. M. C. Ghosh, D. L. Zhang, T. A. Rouault, Iron misregulation and neurodegenerative disease in mouse models that lack iron regulatory proteins. Neurobiol. Dis. 81, 66-75 (2015).

16. K. Pantopoulos, Iron metabolism and the IRE/IRP regulatory system: An update. Ann N. Y. Acad. Sci. 1012, 1-13 (2004).

17. T. Ganz, Systemic iron homeostasis. Physiol. Rev. 93, 1721-1741 (2013)

18. C. P. Anderson, M. Shen, R. S. Eisenstein, E. A. Leibold, Mammalian iron metabolism and its control by iron regulatory proteins. Biochim. Biophys. Acta 1823, 1468-1483 (2012).

19. T. A. Rouault, The role of iron regulatory proteins in mammalian iron homeostasis and disease. Nat. Chem. Biol. 2, 406-414 (2006).

20. V. Sangkhae, E. Nemeth, Regulation of the iron homeostatic hormone hepcidin. Adv. Nutr. 8, 126-136 (2017).

21. I. De Domenico et al., The molecular mechanism of hepcidin-mediated ferroportin down-regulation. Mol. Biol. Cell 18, 2569-2578 (2007).

22. E. Nemeth et al., Hepcidin regulates cellular iron efflux by binding to ferroportin and inducing its internalization. Science 306, 2090-2093 (2004).

23. N. L. Parrow, R. E. Fleming, Bone morphogenetic proteins as regulators of iron metabolism. Annu. Rev. Nutr. 34, 77-94 (2014).

24. C. Y. Wang et al., Smad1/5 is required for erythropoietin-mediated suppression of hepcidin in mice. Blood 130, 73-83 (2017).

25. R. H. Wang et al., A role of SMAD4 in iron metabolism through the positive regulation of hepcidin expression. Cell Metab. 2, 399-409 (2005).

26. E. T. Chouchani et al., Mitochondrial ROS regulate thermogenic energy expenditure and sulfenylation of UCP1. Nature 532, 112-116 (2016).

27. D. I. Kim et al., An OLTAM system for analysis of brown/beige fat thermogenic activity. Int. J. Obes. 42, 939-945 (2018).

28. J. Li et al., Transferrin receptor 1 regulates thermogenic capacity and cell fate in brown/beige adipocytes. Adv. Sci. (Weinh.) 7, 1903366 (2020).
(Li-Cor). The sources and dilutions for antibodies were summarized in SI Appendix, Table 3.

Statistical Analysis. Statistical significance between the two groups was determined using a two-tailed Student's $t$ test. One-way ANOVA followed by Tukey's post hoc correction was applied for multigroup comparisons. $P$ values of less than 0.05 were considered to be significant.

Data Availability. All study data are included in the article and/or SI Appendix.

ACKNOWLEDGMENTS. This work was supported in part by Grants NIH1P20GM104320 (Project 5) and 1R21HD094273 awarded to S.C., NIHDK079209 to J.L., and NIH-5R35GM119770-03 to T.H. from NIH. This study is also supported in part by the Science, Engineering, and Medicine Initiative Grant awarded to S.C. from the University of Nebraska-Lincoln and the Nebraska Established Program to Stimulate Competitive Research (EPSCoR) Grant awarded to S.C. J.-S.Y. received the National Institute of Diabetes and Digestive and Kidney Diseases (NIDDK) scholarship to present the study in the Keystone 2018 symposia.

29. K. Kodo et al., Erythropoietin (EPO) ameliorates obesity and glucose homeostasis by promoting thermogenesis and endocrine function of classical brown adipose tissue (BAT) in diet-induced obese mice. PLoS One 12, e0173661 (2017).

30. J. Zheng, M. Chen, G. Liu, E. Xu, H. Chen, Ablation of hephaestin and ceruloplasmin results in iron accumulation in adipocytes and type 2 diabetes. FEBS Lett. 592, 394-401 (2018).

31. L. Kautz et al., Iron regulates phosphorylation of Smad1/5/8 and gene expression of Bmp6, Smad7, Id1, and Atoh8 in the mouse liver. Blood 112, 1503-1509 (2008)

32. M. C. Ghosh et al., Deletion of iron regulatory protein 1 causes polycythemia and pulmonary hypertension in mice through translational derepression of HIF2 $\alpha$. Cell Metab. 17, 271-281 (2013)

33. M. C. Ghosh, D. L. Zhang, H. Ollivierre, M. A. Eckhaus, T. A. Rouault, Translationa repression of HIF2 $\alpha$ expression in mice with Chuvash polycythemia reverses polycythemia. J. Clin. Invest. 128, 1317-1325 (2018).

34. N. Wilkinson, K. Pantopoulos, IRP1 regulates erythropoiesis and systemic iron homeostasis by controlling HIF2 $\alpha$ mRNA translation. Blood 122, 1658-1668 (2013).

35. E. M. Wallace et al., A small-molecule antagonist of HIF2 $\alpha$ is efficacious in preclinical models of renal cell carcinoma. Cancer Res. 76, 5491-5500 (2016).

36. N. Wlazlo et al., Iron metabolism is associated with adipocyte insulin resistance and plasma adiponectin: The Cohort on Diabetes and Atherosclerosis Maastricht (CODAM) study. Diabetes Care 36, 309-315 (2013).

37. J. S. Gabrielsen et al., Adipocyte iron regulates adiponectin and insulin sensitivity. J. Clin. Invest. 122, 3529-3540 (2012)

38. Y. Gao et al., Adipocyte iron regulates leptin and food intake. J. Clin. Invest. 125, 3681-3691 (2015)

39. Y. Gao et al., Iron down-regulates leptin by suppressing protein O-GICNAc modification in adipocytes, resulting in decreased levels of O-glycosylated CREB. J. Biol. Chem 294, 5487-5495 (2019).

40. M. Festa et al., Overexpression of $\mathrm{H}$ ferritin and up-regulation of iron regulatory protein genes during differentiation of 3T3-L1 pre-adipocytes. J. Biol. Chem. 275, 36708-36712 (2000)

41. M. Moreno et al., Cytosolic aconitase activity sustains adipogenic capacity of adipose tissue connecting iron metabolism and adipogenesis. FASEB J. 29, 1529-1539 (2015).

42. J. Qiu et al., Transferrin receptor functionally marks thermogenic adipocytes. Front. Cell Dev. Biol. 8, 572459 (2020)

43. L. Britton et al., Ferroportin expression in adipocytes does not contribute to iron homeostasis or metabolic responses to a high calorie diet. Cell. Mol. Gastroenterol. Hepatol. 5, 319-331 (2018)

44. E. G. Meyron-Holtz et al., Genetic ablations of iron regulatory proteins 1 and 2 reveal why iron regulatory protein 2 dominates iron homeostasis. EMBO J. 23, 386-395 (2004)

45. S. S. Cooperman et al., Microcytic anemia, erythropoietic protoporphyria, and neurodegeneration in mice with targeted deletion of iron-regulatory protein 2. Blood 106, 1084-1091 (2005)

46. S. A. Anderson et al., The IRP1-HIF-2 $\alpha$ axis coordinates iron and oxygen sensing with erythropoiesis and iron absorption. Cell Metab. 17, 282-290 (2013).

47. E. R. Kim et al., Red blood cell $\beta$-adrenergic receptors contribute to diet-induced energy expenditure by increasing O2 supply. JCI Insight 2, 93367 (2017).

48. M. Yee Koh, T. R. Spivak-Kroizman, G. Powis, HIF-1 regulation: Not so easy come, easy go. Trends Biochem. Sci. 33, 526-534 (2008)

49. E. T. Chouchani, L. Kazak, B. M. Spiegelman, Mitochondrial reactive oxygen species and adipose tissue thermogenesis: Bridging physiology and mechanisms. J. Biol Chem. 292, 16810-16816 (2017)

50. R. García-Martín et al., Adipocyte-specific hypoxia-inducible factor $2 \alpha$ deficiency exacerbates obesity-induced brown adipose tissue dysfunction and metabolic dysregulation. Mol. Cell. Biol. 36, 376-393 (2015).

51. E. Gammella et al., Erythropoietin's inhibiting impact on hepcidin expression occurs indirectly. Am. J. Physiol. Regul. Integr. Comp. Physiol. 308, R330-R335 (2015).

52. L. Kautz et al., Erythroferrone contributes to hepcidin suppression and iron overload in a mouse model of $\beta$-thalassemia. Blood 126, 2031-2037 (2015). 
53. L. Kautz et al., Identification of erythroferrone as an erythroid regulator of iron metabolism. Nat. Genet. 46, 678-684 (2014).

54. J. Arezes et al., Erythroferrone inhibits the induction of hepcidin by BMP6. Blood 132 1473-1477 (2018)

55. A. Kim, E. Nemeth, New insights into iron regulation and erythropoiesis. Curr. Opin Hematol. 22, 199-205 (2015).

56. N. U. Stoffel et al., The effect of central obesity on inflammation, hepcidin, and iron metabolism in young women. Int. J. Obes. 44, 1291-1300 (2020).

57. C. Rose, K. M. Edwards, J. Siegler, K. Graham, C. Caillaud, Whole-body cryotherapy as a recovery technique after exercise: A review of the literature. Int. J. Sports Med. $\mathbf{3 8}$ 1049-1060 (2017).

58. S. Loap, R. Lathe, Mechanism underlying tissue cryotherapy to combat obesity/overweight: Triggering thermogenesis. J. Obes. 2018, 5789647 (2018).

59. K. Dulian et al., The whole body cryostimulation modifies irisin concentration and reduces inflammation in middle aged, obese men. Cryobiology 71, 398-404 (2015).

60. A. Amato et al., Effect of body mass index reduction on serum hepcidin levels and iron status in obese children. Int. J. Obes. 34, 1772-1774 (2010).

61. R. Vuppalanchi et al., Serum hepcidin levels are associated with obesity but not liver disease. Obesity (Silver Spring) 22, 836-841 (2014).

62. E. Aigner, A. Feldman, C. Datz, Obesity as an emerging risk factor for iron deficiency Nutrients 6, 3587-3600 (2014)

63. K. J. Ausk, G. N. loannou, Is obesity associated with anemia of chronic disease? A population-based study. Obesity (Silver Spring) 16, 2356-2361 (2008).

64. C. Becker, M. Orozco, N. W. Solomons, K. Schümann, Iron metabolism in obesity: How interaction between homoeostatic mechanisms can interfere with their original purpose. Part I: Underlying homoeostatic mechanisms of energy storage and iron metabolisms and their interaction. J. Trace Elem. Med. Biol. 30, 195-201 (2015).

65. J. S. Yook et al., Dietary iron deficiency modulates adipocyte iron homeostasis, adaptive thermogenesis, and obesity in C57BL/6 mice. J. Nutr., 10.1093/jn/nxab222 (2021)
66. M. C. Ghosh et al., Tempol-mediated activation of latent iron regulatory protein activity prevents symptoms of neurodegenerative disease in IRP2 knockout mice. Proc. Natl. Acad. Sci. U.S.A. 105, 12028-12033 (2008).

67. M. Okla et al., Activation of Toll-like receptor 4 (TLR4) attenuates adaptive thermogenesis via endoplasmic reticulum stress. J. Biol. Chem. 290, 26476-26490 (2015).

68. Y. Sato et al., Cellular hypoxia of pancreatic $\beta$-cells due to high levels of oxygen consumption for insulin secretion in vitro. J. Biol. Chem. 286, 12524-12532 (2011).

69. C. Fillebeen, N. Wilkinson, K. Pantopoulos, Electrophoretic mobility shift assay (EMSA) for the study of RNA-protein interactions: The IRE/IRP example. J. Vis. Exp. 94, e52230 (2014).

70. E. C. Theil, Iron regulatory elements (IREs): A family of mRNA non-coding sequences. Biochem. J. 304, 1-11 (1994).

71. K. Oexle et al., Dilution of candidates: The case of iron-related genes in restless legs syndrome. Eur. J. Hum. Genet. 21, 410-414 (2013).

72. B. Langmead, S. L. Salzberg, Fast gapped-read alignment with Bowtie 2. Nat. Methods 9, 357-359 (2012).

73. C. Trapnell, L. Pachter, S. L. Salzberg, TopHat: Discovering splice junctions with RNASeq. Bioinformatics 25, 1105-1111 (2009).

74. M. A. Grundy, N. Gorman, P. R. Sinclair, M. J. Chorney, G. S. Gerhard, High-throughput non-heme iron assay for animal tissues. J. Biochem. Biophys. Methods 59, 195-200 (2004).

75. J. Liu et al., Quantitative analysis of murine terminal erythroid differentiation in vivo: Novel method to study normal and disordered erythropoiesis. Blood 121, e43-e49 (2013).

76. J. Kim et al., Eicosapentaenoic acid potentiates brown thermogenesis through FFAR4dependent up-regulation of miR-30b and miR-378. J. Biol. Chem. 291, 20551-20562 (2016). 


\section{Supplemental Information}

\section{Essential role of systemic iron mobilization and redistribution for adaptive thermogenesis through HIF2 $\alpha /$ hepcidin axis}

Short title: Iron mobilization in adaptive thermogenesis

Jin-Seon Yook ${ }^{1 *}$, Mikyoung You ${ }^{1 *}$, Jiyoung Kim²*, Ashley M. Toney ${ }^{3}$, Rong Fan ${ }^{3}$, Bhanwar Lal Puniya ${ }^{4}$, Tomas Helikar ${ }^{4}$, Sophie Vaulont ${ }^{5}$, Jean-Christophe Deschemin ${ }^{5}$, Meshail Okla ${ }^{6}$, Liwei Xie ${ }^{7}$, Manik C. Ghosh ${ }^{8}$, Tracey A. Rouault ${ }^{8}$, Jaekwon Lee ${ }^{4}$, and Soonkyu Chung ${ }^{1,3, \S}$

\section{SI contains \\ Supplemental Table 1-3 \\ Supplemental Figures 1-3}

\section{Supplemental Tables}

Supplemental Table 1. List of iron-related genes used for RNAseq analysis. Published transcriptome dataset (Array Express: E-MTAB-3978) was used ${ }^{5}$. Transcriptome levels are shown as $\log 2$ transformed FPKM values. 'NA'=gene expression not detected.

\begin{tabular}{|c|c|c|c|c|c|c|c|c|c|c|}
\hline \multirow{3}{*}{$\begin{array}{c}\text { Gene } \\
A 2 m\end{array}$} & \multirow{3}{*}{$\begin{array}{l}\text { Full name } \\
\text { alpha-2-macroglobulin }\end{array}$} & \multirow{3}{*}{$\begin{array}{r}\text { White } \\
\text { NA }\end{array}$} & \multirow{2}{*}{\multicolumn{2}{|c|}{ Beige }} & \multicolumn{6}{|c|}{ CL withdrawal (Whitening ) } \\
\hline & & & & & \multicolumn{2}{|c|}{ 5day } & \multicolumn{2}{|c|}{ 10day } & \multicolumn{2}{|c|}{ 30day } \\
\hline & & & NA & NA & NA & NA & NA & NA & NA & NA \\
\hline$A b c b 10$ & $\begin{array}{l}\text { ATP-binding cassette, } \\
\text { sub-family B } \\
\text { (MDR/TAP), member } \\
10\end{array}$ & 0.59 & 1.23 & 0.88 & 1.22 & 0.61 & 0.58 & 1.36 & 0.99 & 1.28 \\
\hline$A b c b 7$ & $\begin{array}{l}\text { ATP-binding cassette, } \\
\text { sub-family B } \\
\text { (MDR/TAP), member } 7\end{array}$ & 2.19 & 1.72 & 2.08 & 1.40 & 0.83 & 1.32 & 1.80 & 1.75 & 1.65 \\
\hline Aco1 & $\begin{array}{l}\text { aconitase 1, soluble; } \\
\text { IREB1; IRP1 }\end{array}$ & 4.60 & 3.25 & 2.99 & 3.62 & 3.10 & 3.93 & 4.04 & 4.48 & 4.47 \\
\hline Alas1 & $\begin{array}{l}\text { aminolevulinic acid } \\
\text { synthase } 1\end{array}$ & 4.64 & 5.55 & 5.09 & 5.01 & 3.87 & 4.50 & 5.01 & 5.41 & 4.71 \\
\hline Alas2 & $\begin{array}{l}\text { aminolevulinate } \\
\text { synthase } 2\end{array}$ & -3.27 & -3.47 & -3.82 & -5.01 & -3.13 & -5.17 & -5.08 & -4.29 & -2.83 \\
\hline Aco2 & $\begin{array}{l}\text { aconitase } 2, \\
\text { mitochondrial }\end{array}$ & 7.54 & 8.80 & 8.56 & 8.98 & 8.50 & 7.37 & 8.42 & 7.87 & 8.17 \\
\hline$B 2 m$ & beta-2-microglobulin & 11.12 & 9.06 & 8.82 & 9.30 & 9.09 & 10.36 & 9.73 & 11.01 & 10.47 \\
\hline $\mathrm{Bmp2}$ & $\begin{array}{l}\text { bone morphogenetic } \\
\text { protein } 2\end{array}$ & -1.63 & -2.56 & -3.74 & -1.26 & -3.51 & -1.49 & -1.86 & -1.39 & -2.41 \\
\hline Bmp4 & $\begin{array}{l}\text { bone morphogenetic } \\
\text { protein } 4\end{array}$ & -5.06 & NA & -5.41 & NA & NA & NA & NA & -5.34 & NA \\
\hline Bmp6 & $\begin{array}{l}\text { bone morphogenetic } \\
\text { protein } 6\end{array}$ & -2.95 & -2.60 & -2.91 & -1.77 & -2.90 & -3.52 & -3.10 & -3.64 & -5.50 \\
\hline Bmpr1a & $\begin{array}{l}\text { bone morphogenetic } \\
\text { protein receptor, type } \\
\text { IA }\end{array}$ & 3.69 & 1.74 & 1.97 & 2.28 & 1.79 & 2.54 & 2.65 & 3.18 & 2.71 \\
\hline
\end{tabular}




\begin{tabular}{|c|c|c|c|c|c|c|c|c|c|c|}
\hline Bmpr1b & $\begin{array}{l}\text { bone morphogenetic } \\
\text { protein receptor, type } \\
\text { IB }\end{array}$ & -7.12 & NA & NA & NA & NA & -5.69 & NA & NA & NA \\
\hline Bmpr2 & $\begin{array}{l}\text { bone morphogenetic } \\
\text { protein receptor, type II } \\
\text { (serine/threonine } \\
\text { kinase) }\end{array}$ & 3.43 & 2.50 & 2.78 & 3.41 & 2.52 & 3.19 & 3.32 & 3.36 & 3.18 \\
\hline Cisd1 & $\begin{array}{l}\text { CDGSH iron sulfur } \\
\text { domain } 1, \text { mitoneet }\end{array}$ & 4.83 & 5.65 & 5.28 & 5.15 & 4.93 & 4.46 & 5.19 & 5.23 & 5.19 \\
\hline Calr & calreticulin & 5.43 & 3.73 & 3.86 & 4.15 & 3.90 & 4.44 & 4.85 & 5.34 & 4.47 \\
\hline Cd163 & $\begin{array}{l}\text { CD163 molecule } \\
\text { (hemoglobin } \\
\text { scavenger) }\end{array}$ & -5.56 & NA & $\mathrm{NA}$ & $\mathrm{NA}$ & -6.42 & -4.13 & -6.35 & -4.57 & NA \\
\hline Cdc14a & $\begin{array}{l}\text { CDC14 cell division } \\
\text { cycle } 14 \text { homolog A (S. } \\
\text { cerevisiae) }\end{array}$ & -1.77 & -1.46 & -1.63 & -2.02 & -2.30 & -1.47 & -1.02 & -1.47 & -1.65 \\
\hline Cdc42bpa & $\begin{array}{l}\text { CDC42 binding protein } \\
\text { kinase alpha (DMPK- } \\
\text { like) }\end{array}$ & 2.01 & 1.23 & 1.78 & 1.24 & 1.24 & 1.55 & 2.01 & 1.95 & 2.07 \\
\hline Cebpa & $\begin{array}{l}\text { CCAAT/enhancer } \\
\text { binding protein } \\
\text { (C/EBP), alpha }\end{array}$ & 5.49 & 3.50 & 3.73 & 4.97 & 4.36 & 5.21 & 4.97 & 5.63 & 5.73 \\
\hline$C p$ & $\begin{array}{l}\text { ceruloplasmin } \\
\text { (ferroxidase) }\end{array}$ & 4.61 & -1.36 & 0.17 & 2.34 & 2.05 & 3.84 & 2.82 & 4.26 & 3.18 \\
\hline Creb3/3 & $\begin{array}{l}\text { cAMP responsive } \\
\text { element binding protein } \\
3 \text {-like } 3\end{array}$ & NA & NA & NA & NA & NA & NA & -4.34 & NA & NA \\
\hline Crp & $\begin{array}{l}\text { C-reactive protein, } \\
\text { pentraxin-related }\end{array}$ & NA & NA & NA & NA & NA & NA & NA & -5.07 & NA \\
\hline Cubn & $\begin{array}{l}\text { cubilin (intrinsic factor- } \\
\text { cobalamin receptor) }\end{array}$ & -9.29 & -7.74 & -8.05 & -4.88 & -4.36 & -5.86 & -5.75 & NA & -6.84 \\
\hline Cybrd1 & $\begin{array}{l}\text { cytochrome b } \\
\text { reductase } 1\end{array}$ & -3.41 & -4.70 & -4.08 & -3.11 & -2.94 & -2.87 & -2.79 & -3.23 & -3.65 \\
\hline Ddit3 & $\begin{array}{l}\text { DNA-damage-inducible } \\
\text { transcript } 3\end{array}$ & 2.27 & 1.67 & 1.22 & 1.59 & 1.75 & 1.98 & 2.76 & 2.38 & 2.12 \\
\hline Dhcr7 & $\begin{array}{l}\text { 7-dehydrocholesterol } \\
\text { reductase }\end{array}$ & 1.70 & 0.54 & -0.13 & 1.42 & 0.68 & 1.13 & 1.49 & 1.05 & 1.07 \\
\hline Egln2 & $\begin{array}{l}\text { egl nine homolog } 2 \text { (C. } \\
\text { elegans) }\end{array}$ & 1.81 & 0.91 & 1.10 & 1.42 & 1.42 & 1.10 & 1.34 & 1.85 & 1.43 \\
\hline Eif2a & $\begin{array}{l}\text { eukaryotic translation } \\
\text { initiation factor } 2 \mathrm{~A} \text {, } \\
65 \mathrm{kDa}\end{array}$ & 3.77 & 2.79 & 3.09 & 3.30 & 3.47 & 3.45 & 2.95 & 3.80 & 3.71 \\
\hline Eif2ak1 & $\begin{array}{l}\text { eukaryotic translation } \\
\text { initiation factor 2-alpha } \\
\text { kinase } 1 ; \mathrm{HRI}\end{array}$ & 2.75 & 2.05 & 1.83 & 2.93 & 2.27 & 2.68 & 2.73 & 2.55 & 2.63 \\
\hline Epas1 & $\begin{array}{l}\text { endothelial PAS } \\
\text { domain protein } 1\end{array}$ & 4.13 & 4.55 & 4.50 & 4.88 & 3.49 & 4.42 & 5.03 & 4.07 & 3.99 \\
\hline Epo & erythropoietin & NA & NA & NA & NA & NA & NA & NA & NA & NA \\
\hline Epor & erythropoietin receptor & -2.42 & -0.65 & -1.81 & -1.46 & -2.04 & -4.08 & -2.40 & -1.87 & -2.74 \\
\hline Exoc6 & $\begin{array}{l}\text { exocyst complex } \\
\text { component } 6\end{array}$ & 2.03 & 1.55 & 1.82 & 2.07 & 2.10 & 1.76 & 1.86 & 1.84 & 1.98 \\
\hline Fbx/5 & $\begin{array}{l}\text { F-box and leucine-rich } \\
\text { repeat protein } 5\end{array}$ & 2.60 & 1.24 & 1.19 & 1.48 & 1.61 & 1.85 & 1.53 & 2.49 & 2.17 \\
\hline Fech & ferrochelatase & 4.27 & 3.71 & 3.43 & 3.72 & 3.20 & 3.64 & 3.84 & 3.92 & 4.03 \\
\hline Fth1 & $\begin{array}{l}\text { ferritin, heavy } \\
\text { polypeptide } 1\end{array}$ & 9.39 & 8.79 & 8.57 & 9.19 & 9.25 & 9.20 & 9.38 & 9.35 & 9.34 \\
\hline Ftl & ferritin, light polypeptide & 9.43 & 6.81 & 5.96 & 8.21 & 8.94 & 9.25 & 9.12 & 9.33 & 9.29 \\
\hline
\end{tabular}




\begin{tabular}{|c|c|c|c|c|c|c|c|c|c|c|}
\hline Furin & $\begin{array}{l}\text { furin (paired basic } \\
\text { amino acid cleaving } \\
\text { enzyme) }\end{array}$ & 1.74 & 1.42 & 0.92 & 1.78 & 0.82 & 1.74 & 1.68 & 1.36 & 1.57 \\
\hline$F x n$ & frataxin & 1.24 & 1.03 & 1.15 & 0.81 & 0.48 & 0.46 & 1.09 & 1.30 & 1.31 \\
\hline Gas6 & growth arrest-specific 6 & 1.84 & -4.53 & -2.37 & 1.18 & 1.21 & 0.57 & 0.53 & 1.52 & 0.70 \\
\hline Gdf15 & $\begin{array}{l}\text { growth differentiation } \\
\text { factor } 15\end{array}$ & -1.62 & NA & NA & -3.04 & NA & -1.61 & NA & NA & -4.17 \\
\hline Gdf2 & $\begin{array}{l}\text { growth differentiation } \\
\text { factor } 2\end{array}$ & NA & NA & NA & NA & NA & NA & NA & NA & NA \\
\hline Glrx5 & glutaredoxin 5 & 4.16 & 4.44 & 4.26 & 3.59 & 3.41 & 3.64 & 3.99 & 4.22 & 3.89 \\
\hline Gstp1 & $\begin{array}{l}\text { glutathione S- } \\
\text { transferase pi } 1\end{array}$ & 4.86 & 2.95 & 2.63 & 4.22 & 4.40 & 4.03 & 4.32 & 4.71 & 4.28 \\
\hline Hamp & $\begin{array}{l}\text { hepcidin antimicrobial } \\
\text { peptide }\end{array}$ & NA & NA & NA & NA & NA & NA & NA & NA & NA \\
\hline Hao1 & $\begin{array}{l}\text { hydroxyacid oxidase } \\
\text { (glycolate oxidase) } 1\end{array}$ & -5.67 & NA & NA & NA & NA & NA & NA & NA & NA \\
\hline Heph & hephaestin & 2.48 & -0.63 & -1.02 & 0.92 & 0.06 & 1.15 & 1.02 & 1.95 & 1.43 \\
\hline Hephl1 & hephaestin-like 1 & 0.00 & -0.52 & -2.06 & -2.16 & -3.68 & -0.91 & -1.45 & -5.84 & -2.31 \\
\hline Hfe & $\begin{array}{l}\text { hemochromatosis type } \\
1\end{array}$ & 2.97 & 2.18 & 1.54 & 0.64 & 0.30 & 0.38 & 1.43 & 1.70 & 1.29 \\
\hline Hfe2 & $\begin{array}{l}\text { hemochromatosis type } \\
2 \text { (juvenile), HFE2A; } \\
\text { hemojuvelin, HJV; } \\
\text { RGMC }\end{array}$ & NA & NA & NA & NA & NA & NA & NA & NA & NA \\
\hline Hif1a & $\begin{array}{l}\text { hypoxia inducible factor } \\
1 \text {, alpha subunit }\end{array}$ & 2.82 & 2.33 & 2.60 & 2.43 & 1.53 & 2.18 & 2.52 & 2.56 & 2.64 \\
\hline Hif2a & $\begin{array}{l}\text { hypoxia-inducible factor } \\
\text { 2-alpha }\end{array}$ & 4.13 & 4.55 & 4.50 & 4.88 & 3.49 & 4.42 & 5.03 & 4.07 & 3.99 \\
\hline Hif3a & $\begin{array}{l}\text { Hypoxia Inducible } \\
\text { Factor } 3 \text { Subunit Alpha }\end{array}$ & -5.97 & NA & NA & NA & NA & -7.13 & -7.03 & -6.25 & NA \\
\hline Hmox1 & $\begin{array}{l}\text { heme oxygenase } \\
\text { (decycling) } 1\end{array}$ & 1.36 & -1.02 & -0.50 & 0.45 & -0.40 & 0.12 & 0.96 & 0.58 & 0.27 \\
\hline Hmox 2 & $\begin{array}{l}\text { heme oxygenase } \\
\text { (decycling) } 2\end{array}$ & 2.69 & 2.40 & 2.37 & 2.28 & 1.98 & 2.35 & 2.02 & 2.76 & 2.72 \\
\hline$H p$ & haptoglobin & 8.80 & 5.60 & 4.93 & 6.21 & 6.69 & 7.74 & 7.94 & 8.21 & 7.57 \\
\hline$H p x$ & hemopexin & NA & -2.30 & -2.92 & NA & NA & NA & -4.64 & -4.84 & NA \\
\hline Ireb2 & $\begin{array}{l}\text { iron-responsive } \\
\text { element binding protein } \\
\text { 2; IRP2 }\end{array}$ & 2.15 & 0.74 & 1.09 & 1.39 & 1.29 & 1.34 & 1.32 & 1.99 & 1.90 \\
\hline Iscu & $\begin{array}{l}\text { iron-sulfur cluster } \\
\text { scaffold homolog (E. } \\
\text { coli) }\end{array}$ & 5.25 & 5.50 & 5.12 & 5.42 & 5.13 & 5.15 & 5.54 & 5.67 & 5.34 \\
\hline Jak2 & Janus kinase 2 & 1.58 & 0.23 & 0.27 & 1.05 & 0.72 & 0.94 & 1.13 & 1.42 & 1.42 \\
\hline Lcn2 & KIT ligand; SCF & 1.19 & NA & -3.94 & -1.60 & -1.39 & 0.24 & 2.84 & 1.05 & -0.13 \\
\hline Lrp1 & lipocalin 2 & 3.25 & 0.38 & 0.58 & 2.84 & 2.11 & 3.20 & 3.57 & 3.52 & 3.06 \\
\hline Lyrm4 & $\begin{array}{l}\text { low density lipoprotein } \\
\text { receptor-related protein } \\
1\end{array}$ & 1.86 & 1.59 & 1.62 & 0.78 & 1.38 & 1.69 & 1.66 & 1.96 & 1.57 \\
\hline
\end{tabular}




\begin{tabular}{|c|c|c|c|c|c|c|c|c|c|c|}
\hline Mapk11 & $\begin{array}{l}\text { mitogen-activated } \\
\text { protein kinase } 11\end{array}$ & -2.97 & -3.85 & -3.74 & -3.79 & -3.92 & -3.96 & -5.45 & -4.07 & -5.52 \\
\hline Mapk12 & $\begin{array}{l}\text { mitogen-activated } \\
\text { protein kinase } 12\end{array}$ & -4.97 & -5.02 & -4.33 & -4.97 & -3.51 & -4.13 & NA & -3.25 & NA \\
\hline Mapk13 & $\begin{array}{l}\text { mitogen-activated } \\
\text { protein kinase } 13\end{array}$ & -5.05 & -4.51 & -3.23 & NA & -3.58 & NA & -4.53 & NA & NA \\
\hline Mapk14 & $\begin{array}{l}\text { mitogen-activated } \\
\text { protein kinase } 14\end{array}$ & 2.76 & 2.72 & 2.34 & 2.92 & 2.29 & 2.18 & 3.28 & 2.79 & 2.52 \\
\hline Mcoln1 & mucolipin 1; TRPML1 & 1.60 & 1.13 & 1.01 & 1.46 & 1.06 & 1.00 & 1.88 & 1.21 & 1.38 \\
\hline Mon1a & $\begin{array}{l}\text { MON1 homolog A } \\
\text { (yeast) }\end{array}$ & 0.10 & -0.80 & -0.74 & -0.14 & 0.13 & 0.43 & 0.50 & 0.17 & -0.19 \\
\hline Neo1 & neogenin 1 & 1.97 & 0.41 & 0.26 & 2.41 & 1.52 & 1.78 & 1.88 & 2.00 & 2.01 \\
\hline Pank2 & pantothenate kinase 2 & 1.20 & 0.55 & 0.72 & 1.14 & 0.77 & 1.22 & 1.39 & 1.68 & 1.43 \\
\hline Pcbp1 & $\begin{array}{l}\text { poly }(\mathrm{rC}) \text { binding protein } \\
1\end{array}$ & 3.53 & 3.04 & 2.96 & 3.61 & 3.00 & 3.43 & 3.49 & 3.66 & 3.46 \\
\hline Pcsk7 & $\begin{array}{l}\text { proprotein convertase } \\
\text { subtilisin/kexin type } 7\end{array}$ & 0.29 & -0.45 & -0.19 & -0.34 & -0.84 & 0.03 & -0.15 & 0.28 & -0.12 \\
\hline Pgrmc1 & $\begin{array}{l}\text { progesterone receptor } \\
\text { membrane component } \\
1\end{array}$ & 4.39 & 3.20 & 3.12 & 3.35 & 3.25 & 3.40 & 3.68 & 3.81 & 3.65 \\
\hline Pgrmc2 & $\begin{array}{l}\text { progesterone receptor } \\
\text { membrane component } \\
2\end{array}$ & 3.54 & 2.46 & 2.35 & 3.46 & 3.10 & 3.40 & 3.51 & 3.57 & 3.19 \\
\hline Pla2g6 & $\begin{array}{l}\text { phospholipase A2, } \\
\text { group VI (cytosolic, } \\
\text { calcium-independent) }\end{array}$ & 1.69 & 0.56 & 0.18 & 1.49 & 0.45 & 1.37 & 1.60 & 1.61 & 1.26 \\
\hline Scara5 & $\begin{array}{l}\text { scavenger receptor } \\
\text { class } A \text {, member } 5 \\
\text { (putative) }\end{array}$ & -1.24 & NA & NA & NA & -6.19 & NA & NA & -4.34 & NA \\
\hline Slc11a1 & $\begin{array}{l}\text { solute carrier family } 11 \\
\text { (proton-coupled } \\
\text { divalent metal ion } \\
\text { transporters), member } \\
1\end{array}$ & -5.88 & -3.75 & -5.64 & -4.29 & NA & -4.45 & -3.77 & -3.25 & -3.85 \\
\hline Slc11a2 & $\begin{array}{l}\text { solute carrier family } 11 \\
\text { (proton-coupled } \\
\text { divalent metal ion } \\
\text { transporters), member } \\
2\end{array}$ & 1.44 & 1.96 & 1.85 & 1.58 & 0.82 & 1.57 & 2.20 & 1.70 & 1.45 \\
\hline Slc22a17 & $\begin{array}{l}\text { solute carrier family } 22, \\
\text { member } 17\end{array}$ & -0.39 & -1.63 & -2.47 & 0.08 & -1.08 & 0.17 & 0.43 & -0.31 & -0.47 \\
\hline Slc25a37 & $\begin{array}{l}\text { solute carrier family } 25, \\
\text { member } 37 ; \text { mitoferrin; } \\
\text { frascati; MSCP; MFRN }\end{array}$ & 0.26 & -0.12 & -0.22 & -0.09 & -0.81 & 0.03 & 0.45 & 0.13 & 0.20 \\
\hline Slc25a38 & $\begin{array}{l}\text { solute carrier family } 25, \\
\text { member } 38\end{array}$ & 0.53 & -0.34 & -0.64 & 0.32 & 0.01 & 0.48 & 0.11 & 0.83 & 0.31 \\
\hline Slc39a8 & $\begin{array}{l}\text { solute carrier family } 39 \\
\text { (metal ion transporter), } \\
\text { member } 8\end{array}$ & -1.05 & -1.18 & -0.85 & -0.36 & -0.97 & -0.49 & 0.34 & -0.21 & -1.71 \\
\hline Slc39a14 & $\begin{array}{l}\text { solute carrier family } 39 \\
\text { (zinc transporter), } \\
\text { member } 14, \text { ZIP14 }\end{array}$ & -0.99 & -2.19 & -1.46 & -1.25 & -0.75 & -0.74 & -0.21 & -1.07 & -2.61 \\
\hline Slc40a1 & $\begin{array}{l}\text { solute carrier family } 40 \\
\text { (iron-regulated } \\
\text { transporter), member 1; } \\
\text { ferroportin, MTP1, } \\
\text { IREG1; FPN1; HFE4 }\end{array}$ & -0.91 & 0.19 & 0.43 & -0.46 & -1.55 & -0.56 & -1.36 & 0.16 & 0.03 \\
\hline
\end{tabular}




\begin{tabular}{|c|c|c|c|c|c|c|c|c|c|c|}
\hline Slc46a1 & 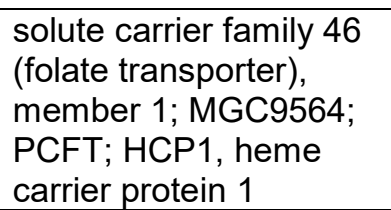 & 1.09 & 0.16 & -0.15 & 0.77 & -0.12 & 0.26 & 0.56 & 0.91 & 0.34 \\
\hline Slc48a1 & $\begin{array}{l}\text { solute carrier family } 48 \\
\text { (heme transporter), } \\
\text { member } 1\end{array}$ & 3.84 & 2.46 & 2.20 & 3.29 & 3.05 & 3.16 & 3.22 & 3.45 & 3.36 \\
\hline Smad1 & SMAD family member 1 & 0.88 & -0.05 & -0.53 & 0.62 & 0.47 & 0.34 & 0.26 & 0.89 & 0.50 \\
\hline Smad2 & SMAD family member 2 & 1.71 & 0.42 & 0.76 & 1.12 & 1.09 & 1.20 & 1.24 & 1.66 & 1.61 \\
\hline Smad3 & SMAD family member 3 & 1.16 & 0.09 & -0.54 & 0.00 & -0.66 & -0.26 & 0.76 & 0.89 & 0.33 \\
\hline Smad4 & SMAD family member 4 & 1.82 & 0.74 & 0.89 & 1.79 & 1.20 & 1.71 & 1.42 & 1.88 & 1.74 \\
\hline Smad5 & SMAD family member 5 & 2.07 & 1.06 & 0.93 & 1.68 & 1.22 & 1.79 & 2.04 & 2.13 & 2.01 \\
\hline Smad6 & SMAD family member 6 & -0.85 & $\begin{array}{c}-1.04 \\
\end{array}$ & -2.04 & -0.23 & -1.11 & 0.06 & 0.25 & -0.19 & 0.36 \\
\hline Smad7 & SMAD family member 7 & -4.89 & -3.35 & -3.66 & -3.30 & -4.84 & -2.76 & -3.55 & -3.41 & -3.45 \\
\hline Smad9 & SMAD family member 9 & -4.27 & -5.06 & -6.95 & -3.26 & -4.72 & -3.43 & -5.65 & -4.29 & -4.74 \\
\hline Stat3 & $\begin{array}{l}\text { signal transducer and } \\
\text { activator of } \\
\text { transcription } 3 \text { (acute- } \\
\text { phase response factor) }\end{array}$ & 3.04 & 1.11 & 0.84 & 2.17 & 1.54 & 2.10 & 2.12 & 2.58 & 2.05 \\
\hline Stat5a & $\begin{array}{l}\text { signal transducer and } \\
\text { activator of } \\
\text { transcription } 5 \mathrm{~A}\end{array}$ & 2.56 & 1.55 & 1.11 & 2.04 & 1.47 & 2.08 & 2.25 & 2.61 & 2.59 \\
\hline Stat5b & $\begin{array}{l}\text { signal transducer and } \\
\text { activator of } \\
\text { transcription } 5 \mathrm{~B}\end{array}$ & 1.06 & -0.08 & -0.26 & 1.24 & 0.43 & 0.60 & 1.01 & 0.88 & 0.99 \\
\hline Steap3 & $\begin{array}{l}\text { STEAP family member } \\
\text { 3; hTSAP6; Dudulin-2 }\end{array}$ & 1.57 & 0.65 & -0.07 & 1.34 & 0.21 & 0.85 & 2.00 & 1.67 & 0.89 \\
\hline Tfr2 & transferrin receptor 2 & -3.81 & -0.76 & -1.82 & -2.46 & -2.87 & -1.50 & -1.40 & -2.50 & -2.07 \\
\hline Tfrc & $\begin{array}{l}\text { transferrin receptor } \\
(\mathrm{p} 90, \mathrm{CD} 71)\end{array}$ & 0.04 & 4.07 & 4.35 & 1.50 & 2.05 & 0.30 & 0.91 & 0.47 & 0.86 \\
\hline Tmprss6 & $\begin{array}{l}\text { transmembrane } \\
\text { protease, serine } 6\end{array}$ & -4.39 & NA & -6.15 & -4.80 & -5.92 & NA & -5.86 & -4.49 & -3.94 \\
\hline Tnf & $\begin{array}{l}\text { tumor necrosis factor; } \\
\text { TNFalpha }\end{array}$ & NA & -4.76 & -4.06 & -3.12 & -4.83 & -4.87 & -4.77 & NA & NA \\
\hline Twsg1 & tumor protein p53 & 2.89 & 1.84 & 2.09 & 2.42 & 1.89 & 2.28 & 2.29 & 3.05 & 2.57 \\
\hline Vhl & $\begin{array}{l}\text { twisted gastrulation } \\
\text { homolog } 1 \text { (Drosophila) }\end{array}$ & 1.02 & -0.21 & -0.45 & -0.27 & -0.39 & -0.29 & 0.47 & 1.02 & 0.23 \\
\hline$X d h$ & $\begin{array}{l}\text { von Hippel-Lindau } \\
\text { tumor suppressor }\end{array}$ & 2.87 & 0.79 & 0.47 & 2.46 & 1.98 & 3.08 & 2.62 & 2.78 & 2.37 \\
\hline
\end{tabular}


Supplemental Table 2. List of primer sequences for qPCR

\begin{tabular}{|c|c|c|}
\hline Primer & Primer sequence & Size \\
\hline Hamp1 & $\begin{array}{l}\text { F: 5'-CAACTTCCCCATCTGCATCT-3' } \\
\text { R: 5'-GCAGGGGTGTAGAGAGGTCA-3' }\end{array}$ & 108 \\
\hline Ucp1 & $\begin{array}{l}\text { F: 5'-AGGCTTCCAGTACCATTAGGT-3' } \\
\text { R: 5'-CTGAGTGAGGCAAAGCTGATTT-3' }\end{array}$ & 133 \\
\hline Cidea & $\begin{array}{l}\text { F: 5'-TGCTCTTCTGTATCGCCCAGT-3' } \\
\text { R: 5'-GCCGTGTTAAGGAATCTGCTG-3' }\end{array}$ & 113 \\
\hline $\operatorname{Tfr} 1(\mathrm{Cd} 71)$ & $\begin{array}{l}\text { F: 5'-AGCCAGATCAGCATTCTCTAAC-3' } \\
\text { R: 5'-TCTGCAGCCAGTTTCATCTC-3' }\end{array}$ & 117 \\
\hline Fpn & $\begin{array}{l}\text { F: 5'-CTACCATTAGAAGGATTGACCAGCTA-3' } \\
\text { R: 5'-CTGGAGAACCAAATGTCATAATCTG-3' }\end{array}$ & 81 \\
\hline Erfe & $\begin{array}{l}\text { F: 5'-ATGGGGCTGGAGAACAGC-3' } \\
\text { R: 5'-TGGCATTGTCCAAGAAGACA-3' }\end{array}$ & 100 \\
\hline$K i-67$ & $\begin{array}{l}\text { F: 5'-ATCATTGACCGCTCCTTTAGGT-3' } \\
\text { R: 5'-GCTCGCCTTGATGGTTCCT-3' }\end{array}$ & 104 \\
\hline Cyclina & $\begin{array}{l}\text { F: 5'-CTGGTTGAGGTGGGAGAAGA-3' } \\
\text { R: 5'-ATAGCAGCCGTGCCTACAAG-3' }\end{array}$ & 131 \\
\hline Epor & $\begin{array}{l}\text { F: 5'-GTCTGACTTGGCCTCAAAGC-3' } \\
\text { R: 5'-GTGAGGTGGAGTGGGAGGTA-3' }\end{array}$ & 133 \\
\hline Nix & $\begin{array}{l}\text { F: 5'-CTGGTCCAGTAGACCCGAAA-3' } \\
\text { R: 5'-CTTCATGGCTCCACTCTTCC-3' }\end{array}$ & 100 \\
\hline $36 b 4$ & $\begin{array}{l}\text { F: 5'-GGATCTGCTGCATCTGCTTG-3' } \\
\text { R: 5'-GGCGACCTGGAAGTCCAACT-3' }\end{array}$ & 113 \\
\hline
\end{tabular}


Supplemental Table S3. List of primary antibodies

\begin{tabular}{|c|c|c|c|c|}
\hline Antibody & Host & Dilution & Company & Catalog no. \\
\hline Ucp1 & Rabbit & $1: 1000$ & Cell Signaling & 14670 \\
\hline Irp1 & Mouse & $1: 1000$ & Generously gifted by Dr. Rouault & \\
\hline Irp2 & Rabbit & $1: 1000$ & Cell Signaling & 37135 \\
\hline Tfr1 & Mouse & $1: 250$ & Thermo Fisher Scientific & $13-6800$ \\
\hline Ftl & Rabbit & $1: 1000$ & Abcam & $a b 69090$ \\
\hline Dmt1 & Rabbit & $1: 1000$ & Cell Signaling & 15083 \\
\hline Cytc & Rabbit & $1: 1000$ & Cell Signaling & 4280 \\
\hline Oxphos & Mouse & $1: 250$ & Abcam & $a b 110413$ \\
\hline Fbxl5 & Rabbit & $1: 200$ & Thermo Fisher Scientific & PA5-42296 \\
\hline Iscu & Mouse & $1: 100$ & Santa Cruz Biotechnology & sc-373694 \\
\hline Bmp6 & Rabbit & $1: 1000$ & Cell signaling & 70583 \\
\hline Bmpr1a & Rabbit & $1: 1000$ & Abcam & ab38560 \\
\hline p-smad1/5 & Rabbit & $1: 1000$ & Cell Signaling & 9516 \\
\hline p-smad1/5/8 & Rabbit & $1: 1000$ & Cell Signaling & 13820 \\
\hline Smad4 & Rabbit & $1: 1000$ & Cell Signaling & 38454 \\
\hline Fpn & Rabbit & $1: 1000$ & Invitrogen & PA5-22993 \\
\hline $\mathrm{Cd} 44$ & Sheep & $1: 2000$ & R\&D Systems & AF6127 \\
\hline $\mathrm{Cp}$ & Goat & $1: 2000$ & Bethyl Laboratory & A80-124 \\
\hline Hif2 $\alpha$ & Mouse & 1:1000 & Novus Biologicals & NB100-132SS \\
\hline Hif1 $\alpha$ & Mouse & $1: 1000$ & Cell Signaling & 79233 \\
\hline Akt & Rabbit & $1: 1000$ & Cell Signaling & 9272 \\
\hline$\beta$-actin & Rabbit & $1: 1000$ & Cell Signaling & 4967 \\
\hline Gapdh & Mouse & $1: 1000$ & Santa Cruz Biotechnology & sc-137179 \\
\hline
\end{tabular}

\begin{tabular}{|l|l|l|}
\hline \multicolumn{2}{|l|}{ Antibodies (Flow cytometry) } \\
\hline eFlore 450 & eBioscience & $65-0842-85$ \\
\hline APC-Cy7-CD45 & eBioscience & $25-0451-82$ \\
\hline APC-Cy7-CD116 & eBioscience & $14-1169-82$ \\
\hline APC-Cy7-GR1 & eBioscience & $17-5937-82$ \\
\hline FITC-CD71 & eBioscience & $11-0711-82$ \\
\hline PE-TER119 & eBioscience & $12-5921-82$ \\
\hline
\end{tabular}




\title{
Supplemental Figure 1
}
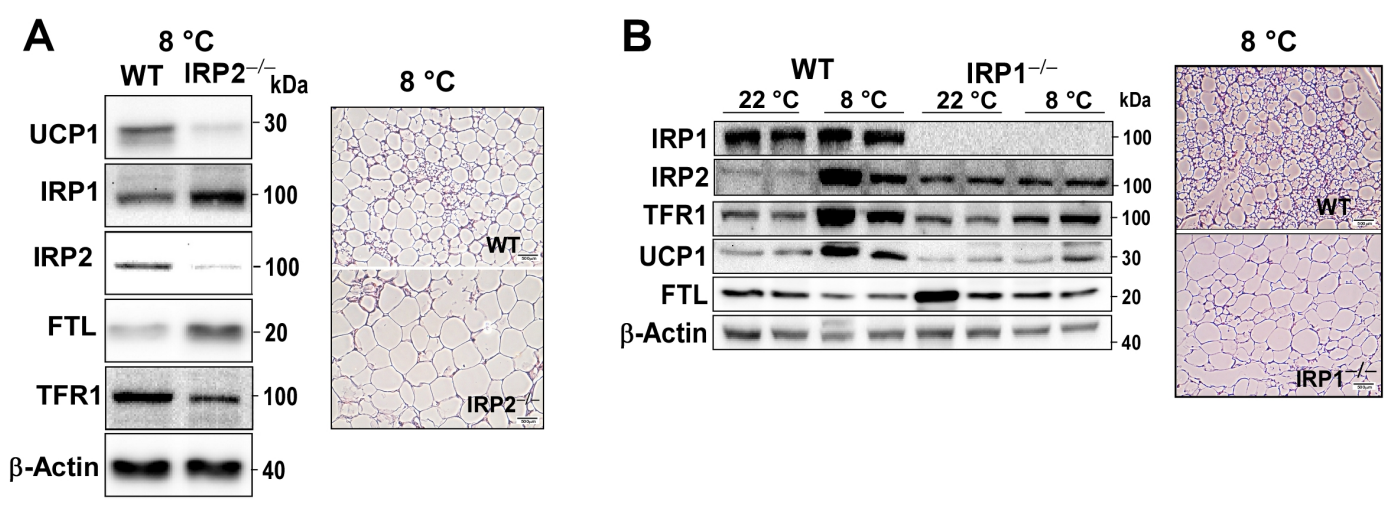

Supplemental Figure 1. (A) Western blot analysis of the iron-related proteins of the iWAT from Irp2 $\mathrm{KO}$ mice kept at cold temperature $\left(8^{\circ} \mathrm{C}\right)$ and $\mathrm{H} \& E$ staining images of iWAT. $\mathrm{N}=3 / \mathrm{group}(\mathrm{B})$ Western blot analysis of iron-handling proteins of the iWAT from Irp1 KO mice kept at either ambient $\left(22^{\circ} \mathrm{C}\right)$ or cold temperature $\left(8^{\circ} \mathrm{C}\right)$, and $\mathrm{H} \& \mathrm{E}$ staining images of iWAT. $\mathrm{N}=5$ /group

\section{Supplemental Figure 2}

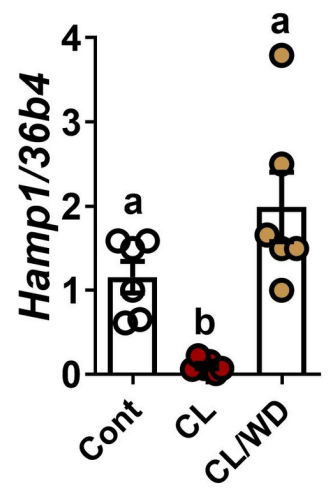

\author{
Supplemental Figure 2. Hamp1 gene \\ expression iWAT. For induction of browning, \\ C57BL/6 mice were administered with either saline \\ (Cont) or 33 -adrenergic receptor (ADRB3) agonist \\ CL 316,243 (CL) for five consecutive days. For the \\ reversal of browning (whitening), the mice that \\ received $C L$ for the first five days were injected \\ with saline for an additional five days for $\mathrm{CL}$ \\ withdrawal (CL/WD) (See study design Fig 1A). \\ mRNA expression of adipocyte Hamp1 gene \\ expression in iWAT was determined by qPCR
}




\section{Supplemental Figure 3}

A

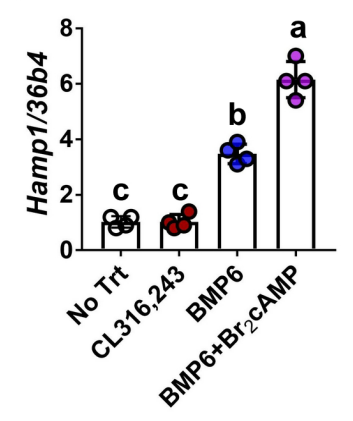

B

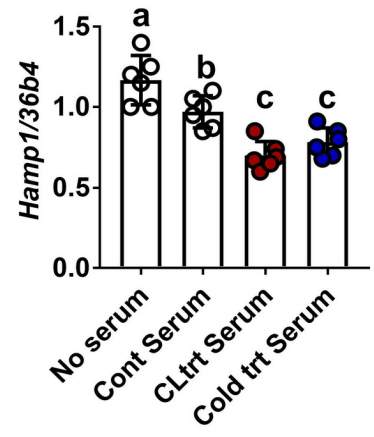

Supplemental Figure 3.

ADRB3 activation

indirectly regulate the

hepatocyte hepcidin

regulation. HepG2 cells

were seeded in 96 well

plate the day before serum addition. Each

wall contains given

chemicals $(A)$ or $10 \%$

serum (B). After 6 hours incubation with serum,

HepG2 cell collected Hamp1 gene expression by qPCR. (A) HepG2 cells added with either CL316,243 (CL, $20 \mathrm{nM})$, BMP6 (10 ng/mL) or BMP6 plus dibutyl-cAMP (0.5 mM). (B)

Serum samples are prepared from animals received either PBS (control), CL injection (CL) or cold treatment (see Animals in Material and Method Section). 